\title{
Fluid Inclusions and H-O-C-S-Pb Isotope Studies of the Xinmin Cu-Au-Ag Polymetallic Deposit in the Qinzhou-Hangzhou Metallogenic Belt, South China: Constraints on Fluid Origin and Evolution
}

\author{
Rui-Chun Duan $\mathbb{D}^{1,2}$ and Shao-Yong Jiang $\mathbb{D}^{1}$ \\ ${ }^{1}$ State Key Laboratory of Geological Processes and Mineral Resources, School of Earth Resources, Collaborative Innovation Center for \\ Exploration of Strategic Mineral Resources, China University of Geosciences, Wuhan 430074, China \\ ${ }^{2}$ Wuhan Center of Geological Survey, Central South China Innovation Center for Geosciences, China Geological Survey, \\ Wuhan 430205, China
}

Correspondence should be addressed to Shao-Yong Jiang; shyjiang@cug.edu.cn

Received 12 April 2021; Revised 8 June 2021; Accepted 24 June 2021; Published 26 July 2021

Academic Editor: Harris Chris

Copyright (C) 2021 Rui-Chun Duan and Shao-Yong Jiang. This is an open access article distributed under the Creative Commons Attribution License, which permits unrestricted use, distribution, and reproduction in any medium, provided the original work is properly cited.

\begin{abstract}
Qinzhou-Hangzhou metallogenic belt is an important polymetallic ( $\mathrm{Cu}, \mathrm{Mo}, \mathrm{W}, \mathrm{Sn}, \mathrm{Pb}, \mathrm{Zn}, \mathrm{Au}$, and $\mathrm{Ag}$ ) belt in South China. The Xinmin polymetallic deposit is located in the southwestern segment of this belt, which ore bodies hosted in the contact zone of granite and Lower Devonian sedimentary strata and in the structure fractured zone within the strata. Three hydrothermal stages can be distinguished: quartz+tourmaline+pyrite (early stage), tourmaline+pyrite+galena+bismuthinite+ sphalerite+chalcopyrite+pyrrhotite (main stage), and quartz+calcite+dolomite (late stage). The mineralizing fluid system can be described as aqueous with medium-high salinity (2.7-50.7 wt.\%o $\mathrm{NaCl}$ equiv. in the main stage and $0.18-8.81$ wt.\%o $\mathrm{NaCl}$ equiv. in the late stage) and medium-high temperature of $485^{\circ} \mathrm{C}$ to $205^{\circ} \mathrm{C}$ (main stage) and $300^{\circ} \mathrm{C}$ to $116^{\circ} \mathrm{C}$ (late stage). The trapping pressures varied from $2 \mathrm{MPa}$ to $30 \mathrm{MPa}$ (main stage) and $0.4 \mathrm{MPa}$ to $9 \mathrm{MPa}$ (late stage). The $\delta^{18} \mathrm{O}$ values of quartz range from $6.7 \%$ to $8.5 \%$, and the $\delta \mathrm{D}$ values for fluid inclusions in quartz range from $-45 \%$ o to $-52 \%$. The calcite has C-isotopes ranging from $-5.8 \%$ to $+0.7 \%$ and $\mathrm{O}$-isotopes from $+12.7 \%$ o to $21.4 \%$. $\mathrm{H}-\mathrm{O}-\mathrm{C}$ isotope data are consistent with a hydrothermal fluid derived from the Cretaceous granitoid magma. The $\delta^{34} S$ values of sulfides are $-3.3 \%$ to $+1.9 \%$. Sulfides have ${ }^{206} \mathrm{~Pb} /{ }^{204} \mathrm{~Pb}$ ratios of 18.377 to $18.473,{ }^{207} \mathrm{~Pb} /{ }^{204} \mathrm{~Pb}$ ratios of 15.606 to 16.684 , and ${ }^{208} \mathrm{~Pb} /{ }^{204} \mathrm{~Pb}$ ratios of 38.613 to 38.902 . The $\mathrm{S}-\mathrm{Pb}$ isotope data suggest derivation of $\mathrm{S}$ and $\mathrm{Pb}$ mainly from the Cretaceous granitic magma. It is concluded that the Xinmin deposit is a medium-high temperature, medium-high salinity hydrothermal polymetallic deposit, related to the granitic magmatism and strictly controlled by the fault and shattered zones.
\end{abstract}

\section{Introduction}

Knowledge of the sources of ore-forming components can provide valuable background information in evaluating mineral potential and target area selection in regional exploration programs $[1,2]$. Light stable isotopes are widely used for tracing sources and physical-chemical peculiarities of fluids and their components in various types of hydrothermal ore deposits. Numerous studies on the $\mathrm{O}, \mathrm{H}, \mathrm{C}, \mathrm{S}$, and $\mathrm{Pb}$ isotope systematics in polymetallic deposits have been applied to trace the origin of ore-forming fluids [3-8]. The motivation for our research was to use a combination of multi-isotopes (H-O-C$\mathrm{S}-\mathrm{Pb}$ ) and fluid-inclusion characteristics, to carry out the characterization of hydrothermal fluids in a polymetallic deposit. Although the target deposit of our studies, the Xinmin polymetallic is not endowed with world-class ore resources, and 


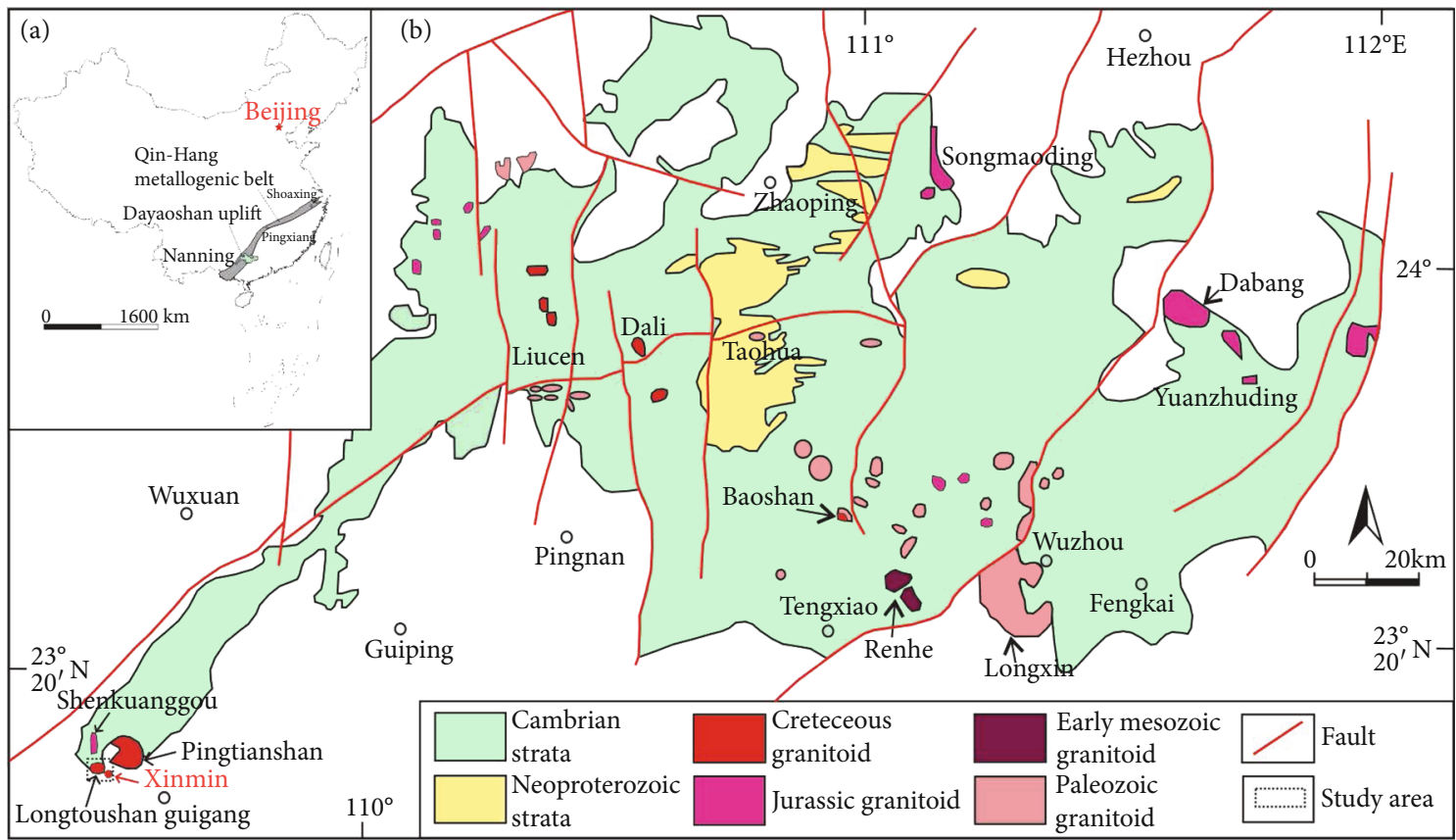

Figure 1: (a) Sketch map showing the location of Dayaoshan Uplift in the Qinzhou-Hangzhou metallogenic belt, South China. (b) Sketch map of the Dayaoshan Uplift. Modified after [16].

it is an interesting area for study because it is a part of magmatic rock-related hydrothermal $\mathrm{Cu}-\mathrm{Au}-\mathrm{Ag}$ polymetallic ore system, with great potential for future exploration.

The Xinmin $\mathrm{Cu}-\mathrm{Au}-\mathrm{Ag}$ polymetallic deposit is located in the southeastern region of the Dayaoshan Uplift (Figure 1). Polymetallic mineralization can be divided into two types in the deposit: (1) veins in the contact zone between Pingtianshan pluton and Devonian strata and (2) layer-like ore body in the structure fractured zone of the Yujiang Formation $[9,10]$. Several studies have been carried on the geology, geochemistry, and the source of metals [9-11]. However, the origin and evolution of ore-forming fluid of the Xinmin deposit are still ambiguous. Some previous studies show that the arsenopyrite and pyrite are the main auriferous minerals; meanwhile, bismuthinite is the host for silver on the basis of geochemistry from sulfide [9]. The ore-forming fluids were medium-high temperature on the basis of skarnization of rocks [9]. The ore-forming fluids were medium-high salinity on the basis of microthermometric data of similar nearby deposit [11]. Previous research is the most based on the observation of field, ore textures, and whole-rock geochemistry. There is no systematic petrographic and microthermometric data for the fluid inclusions and in situ geochemical data for the sulfide minerals. In this study, we identified three hydrothermal stages and presented a detailed sulfide and fluid inclusions study from different stages to characterize the nature of the ore-forming fluids of the Xinmin deposit and to reconstruct the temperature-pressure condition for the mineralization. In addition, based on the isotopic compositions $(\mathrm{C}-\mathrm{H}-\mathrm{O}-\mathrm{S}-\mathrm{Pb})$, we try to trace the sources for ore materials and fluids and to unravel the ore-forming conditions and ore genesis.

\section{Regional Geology}

The Qinzhou-Hangzhou metallogenic belt (QHMB) is one of the most important metallogenic belts in South China, interpreted as a large tectonic suture zone between the Yangtze and Cathaysia blocks that has experienced multistage orogeny from the Neoproterozoic to the Mesozoic. The suture is about $2000 \mathrm{~km}$ long and $70-130 \mathrm{~km}$ wide, extending from the Qinzhou Bay in Guangxi to Hangzhou Bay in Zhejiang (Figure 1(a)). The QHMB is an intraplate polymetallic $(\mathrm{Cu}, \mathrm{Mo}, \mathrm{W}, \mathrm{Sn}, \mathrm{Pb}, \mathrm{Zn}, \mathrm{Au}$, and $\mathrm{Ag}$ ) belt, most of which are related to the granitic rocks spatially and temporally [12-15]. The Dayaoshan Uplift consists of weakly metamorphosed basement and is situated in the southwestern margin of the QHMB (Figure 1(a)). The strata exposed in this area consist mainly of the Neoproterozoic and the Cambrian strata, composed dominantly of greywackes with some interlayers of argillites and silty shales (Figure 1(b)). The main structures in the region include the EW-trending Dayaoshan anticlinorium and the Dali deep fault, on which NE-, NW-, and SN-trending structures are superimposed (Figure 1(b)). Widespread granitic intrusions in the Dayaoshan area emplaced during four stages: Caledonian (470-430 Ma), Hercynian-Indosinian (270-240 Ma), early Yanshanian (170$150 \mathrm{Ma})$, and late Yanshanian (110-90 Ma) [16]. The ore deposits related to granitoids can be divided into three metallogenic series, Caledonian (430-440 Ma) porphyry-skarn and quartz vein type W-Mo metallogenic series, early Yanshanian (145-155 Ma) porphyry type $\mathrm{Cu}-\mathrm{Mo}(-\mathrm{Au})$ metallogenic series, and late Yanshanian (90-110 Ma) porphyry and fracture-controlled alteration type $\mathrm{Mo}-\mathrm{Au}-\mathrm{Ag}-\mathrm{Cu}-\mathrm{Pb}-\mathrm{Zn}$ metallogenic series [16]. 


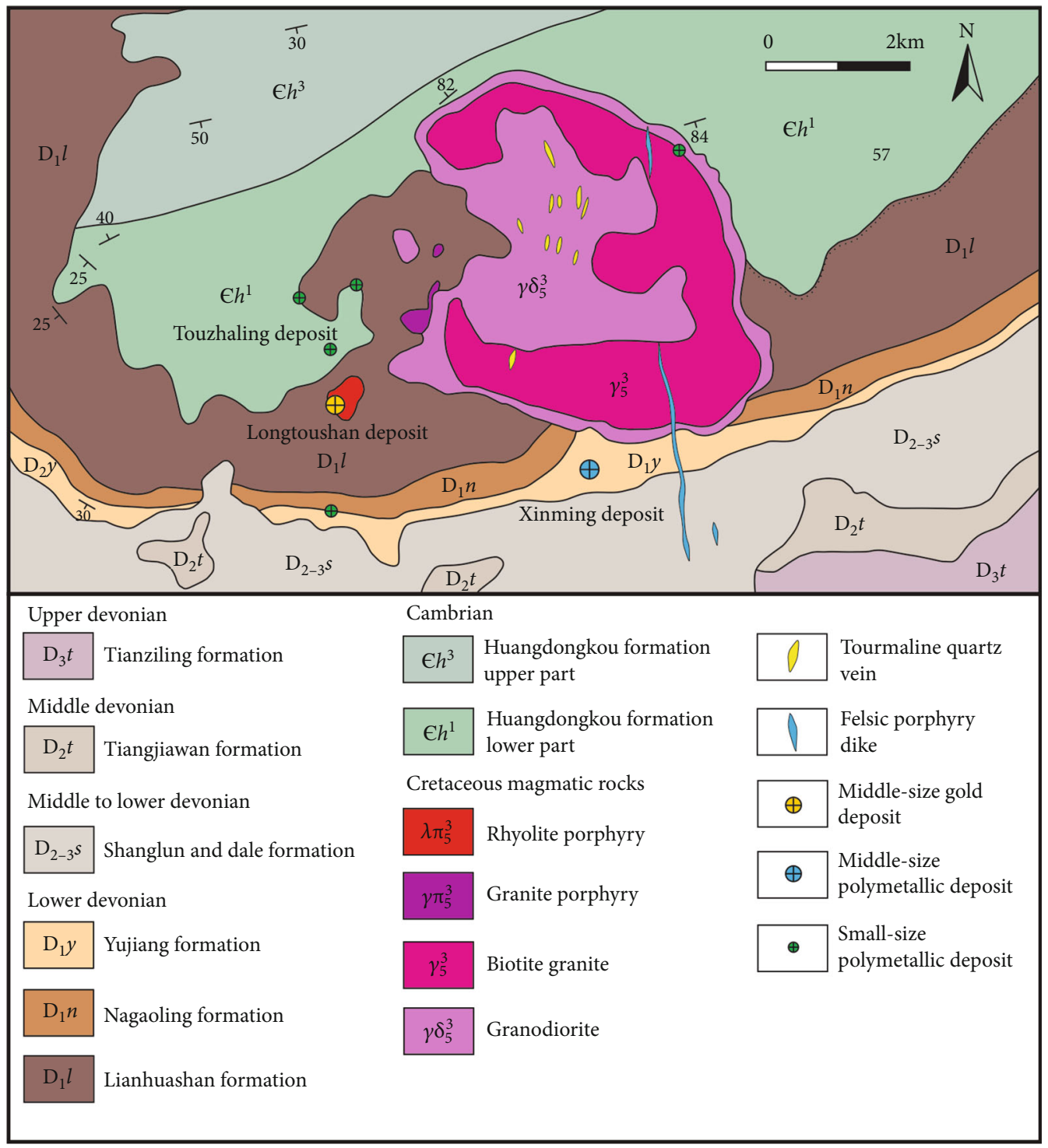

FIGURE 2: Simplified geological map of the Xinmin area showing the location of the Xinmin and other deposits (modified from [17]).

\section{Deposit Geology}

The Xinmin deposit is located at the southwestern of the Dayaoshan region. The strata outcropped in the mining area include the Cambrian Huandongkou Formation; Lower Devonian Lianhuashan Formation, Nagaoling Formation, Yujiang Formation; Middle Devonian Tangjiawan Formation; Upper Devonian Tianziling Formation; and the Quaternary (Figure 2). The Cambrian is composed of siltstone, argillaceous siltstone, shale, limestone, and sandstone; the Devonian consists of dolomite, limestone, marlite, siltstone, silty mudstone, argillaceous siltstone, shale, and basal conglomerate.

Only a small number of Late Cretaceous granites and subvolcanic rocks are distributed in the north and northwest of the mining area (Figure 2). The Pingtianshan granite pluton, with an outcrop area of $29 \mathrm{~km}^{2}$, includes biotite granite and granodiorite. The Longtoushan subvol- canic rocks, with an outcrop area of $0.5 \mathrm{~km}^{2}$, consist of rhyolite porphyry and granitic porphyry. The granodiorite yielded a LA-ICP-MS zircon U-Pb age of $96.5 \pm 0.7 \mathrm{Ma}$ (our unpublished data), which is consistent with the age of rhyolite porphyry and granitic porphyry [17, 18] and its geochemistry indicates that it belongs to the highly potassic and strongly peraluminous series [17].

The occurrence of ore bodies in the Xinmin deposit is strictly controlled by the EW-trending faulted and shattered zone between the Pingtianshan granodiorite pluton and the Devonian Formation and the NS-trending fault in the area (Figure 3). The EW-trending faulted and shattered zone, which inclines $70^{\circ}-80^{\circ}$ to the south and extends up to $1 \mathrm{~km}$, is in the southeastern part of the mining area. The NS-trending fault, which is filled by the granite porphyry and mineralized tourmaline-quartz vein and extends up to $0.5-2.0 \mathrm{~km}$, is located in the western part of the mining area. Twelve ore bodies have been identified in the mining 


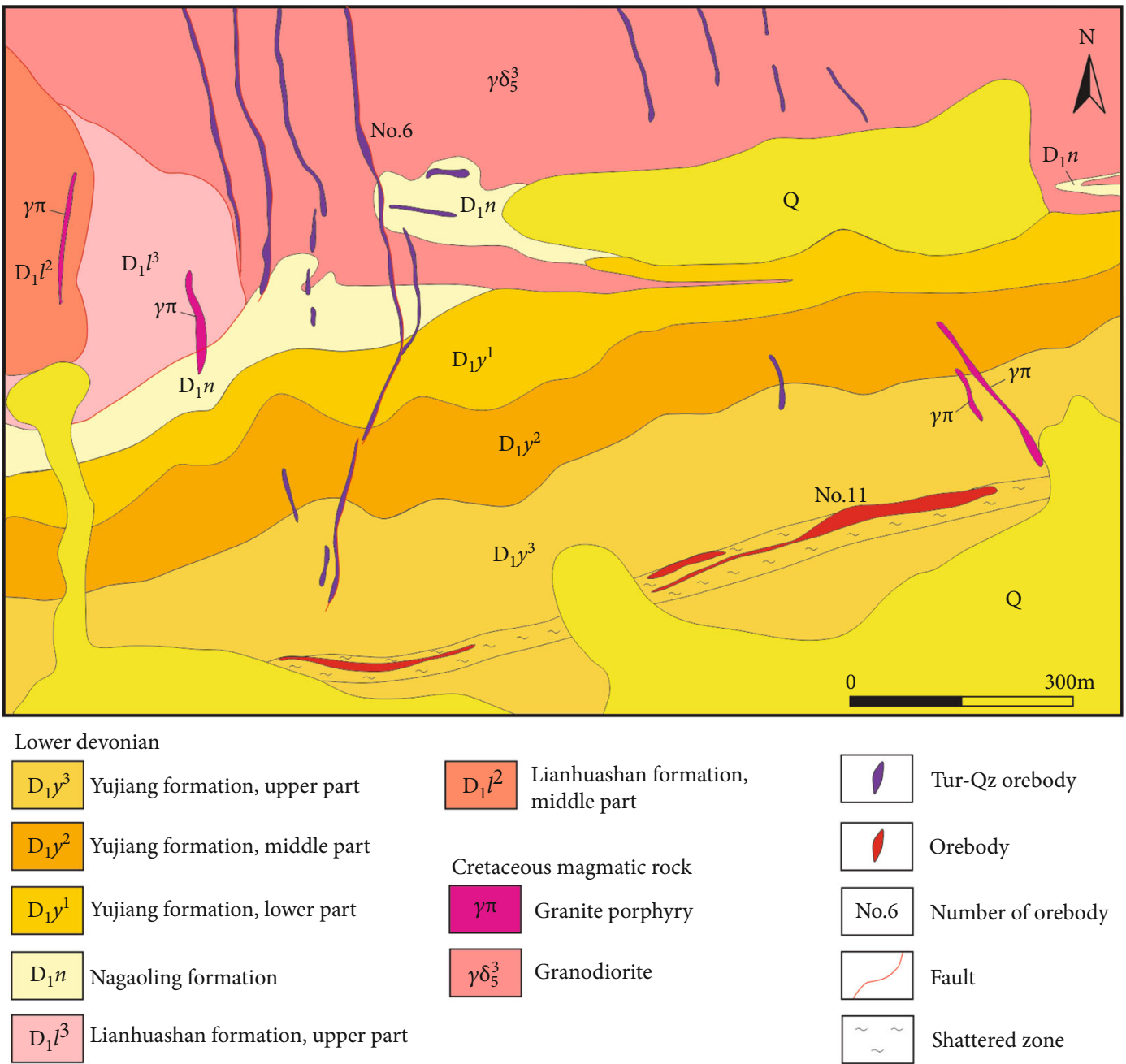

Figure 3: Geological map of the Xinmin polymetallic deposit.

area. The largest ore body (No. 6), NS-trending, with the inclination of the north at an angle of $65^{\circ} \mathrm{C}-85^{\circ} \mathrm{C}$, expands more than $2.65 \mathrm{~km}$ in length and $0.5-5 \mathrm{~m}$ in width, and the average grades of which are $380 \mathrm{~g} / \mathrm{t} \mathrm{Ag}, 0.50 \mathrm{~g} / \mathrm{t} \mathrm{Au}$, and $0.74 \% \mathrm{Cu}[9]$.

The breccia- and vein-type ores in the Xinmin deposit are the main ore types with multiple sulfides (Figures 4(a)-4(c)). In the breccia-ore, breccias include sulfides, quartz and tourmaline. The matrix is tourmalinegranite porphyry, similar with the Longtoushan subvolcanic rock (Figure 4(b)). The main sulfides include pyrite, bismuthinite, sphalerite, chalcopyrite, marcasite, and galena (Figures 4(d)-4(i)), and minor arsenobismite and argentite are also reported [9]. The large, euhedral pyrite (PyI) grains disseminated in the tourmaline+quartz rock (Figures $4(\mathrm{~h})$ and $4(\mathrm{j})$ ). The subhedral pyrite (PyII) intergrows with chalcopyrite and sphalerite (Figure 4(f)). The chalcopyrite commonly occurs within sphalerite as exsolution (Figure 4(f)). The main gangue minerals are tourmaline, quartz, chlorite, actinolite, biotite, anatase, apatite, and tremolite (Figures 4(g) and 4(j)-4(l)). The hydrothermal alterations associated with $\mathrm{Au}-\mathrm{Ag}-\mathrm{Cu}$ mineralization in the Xinmin deposit mainly include tourmalinization, chloritization, carbonation, and silicification.

On the basis of mineral assemblages and the crosscutting relationship, the mineralization process at the Xinmin deposit can be divided into skarn stages and hydrothermal stages. The hydrothermal stages could be subdivided into three stages, namely, (1) the early stage characterized by the assemblages of quartz+tourmaline+pyrite (PyI) (Figures 4(h) and 4(j)), (2) the main ore stage characterized by tourmaline+pyrite (PyII)+galena (GnII)+bismuthinite (BmII)+sphalerite (SpII)+chalcopyrite (CcpII)+ pyrrhotite (PoII) (Figures $4(\mathrm{~d})-4(\mathrm{~g})$ and $4(\mathrm{i})$ ), and (3) the late stage characterized by quartz+calcite+dolomite veins (Figure 4(k)).

The main silver-bearing minerals include nature silver (Figures 5(a) and 5(b)) and bismuthinite (Figure 5(c)), pyrite, and pyrrhotite are also reported [9]. Commonly, these minerals appeared in and between the fissures of quartz, chalcopyrite, tourmaline, and potassium feldspar (Figures 5(a)-5(f)). The size of silver-bearing minerals varies 


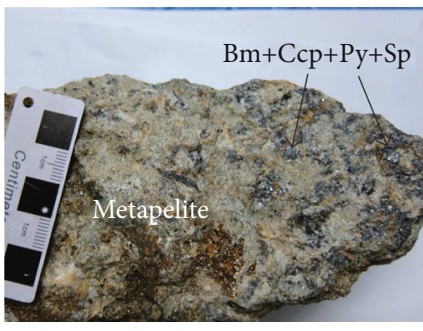

(a)

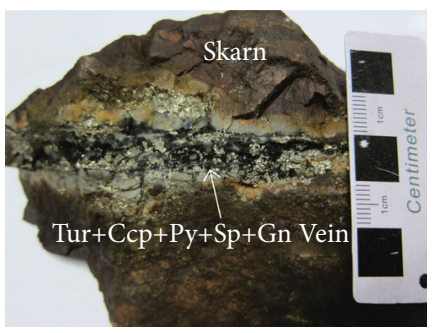

(c)

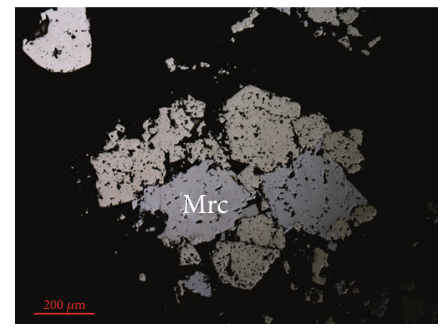

(e)

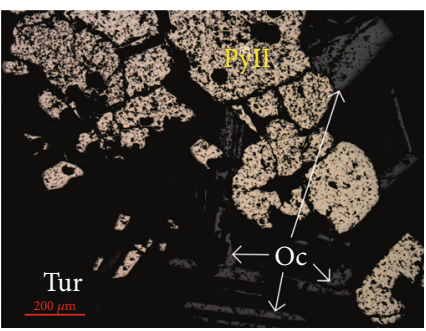

(g)

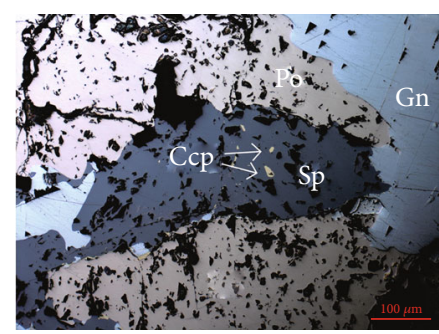

(i)

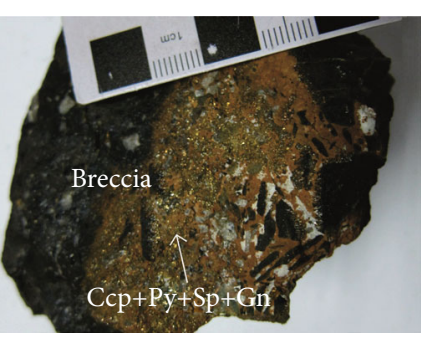

(b)

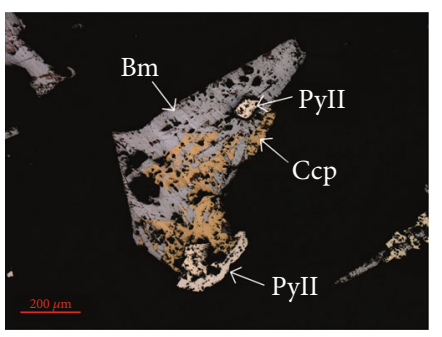

(d)

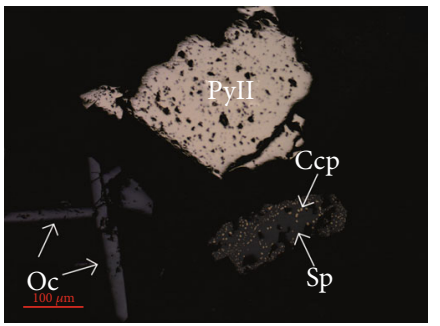

(f)

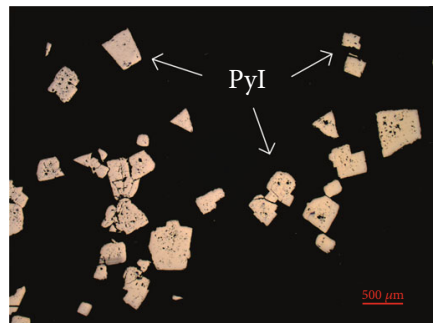

(h)

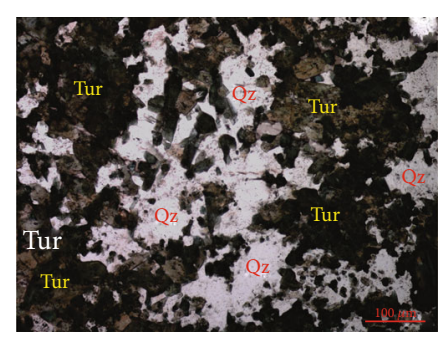

(j)

FIGURE 4: Continued. 


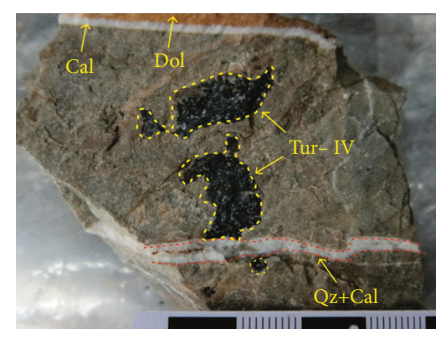

$(\mathrm{k})$

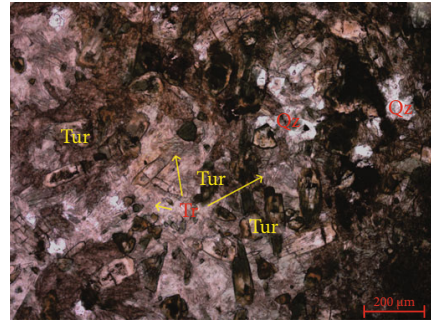

(1)

FIgURE 4: Photographs of hand specimens and photomicrographs showing mineral assemblages of the Xinmin deposit. (a) Bismuthinite, pyrite, sphalerite, and chalcopyrite filling in the metapelite. (b) Pyrite, sphalerite, chalcopyrite, and galena disseminated in the breccia. (c) Tourmaline, pyrite, sphalerite, chalcopyrite, and galena occurring as vein in skarn. (d) The chalcopyrite was replaced by bismuthinite. (e) The optical heterogeneity of marcasite, late stage. (f) Chalcopyrite as emulsion droplet within sphalerite, making an exsolution texture. (g) Octahedrite and anhedral pyrite (PyII). (h) Euhedral pyrite (PyI) in the skarn. (i) Simultaneous pyrrhotite, sphalerite, and galena. (j) Euhedral fine grain-size tourmaline and quartz. (k) Quartz, calcite, and dolomite vein in the skarn. (l) Short columnar tourmaline, anhedral quartz, and fabric tremolite in the skarn. Mineral abbreviations (after [19]): Bm: bismuthinite; Ccp: chalcopyrite; Cal: calcite; Dol: dolomite; Gn: galena; Mrc: marcasite; Oc: Octahedrite; Po: pyrrhotite; Py: pyrite; Sp: sphalerite; Tr: tremolite; Tur: tourmaline.

from $1 \mu \mathrm{m}$ to $20 \mu \mathrm{m}$. The main gold-bearing minerals include nature gold (Figures $5(\mathrm{~g})-5(\mathrm{j})$ ), pyrite, and arsenopyrite are also reported [9]. These minerals are disseminated in quartz, sulfides (pyrite, chalcopyrite), and tourmaline (Figures $5(\mathrm{~g})$ and $5(\mathrm{i}))$. The size of nature gold varies from $1 \mu \mathrm{m}$ to $5 \mu \mathrm{m}$. Fluorite frequently occurs in the surround of Au/Ag-bearing minerals (Figures 5(c) and 5(e)).

\section{Samples and Analytical Methods}

4.1. Samples. Thirty-three samples were collected from the Xinmin deposit in the open pit and roadway. Polished blocks and thin sections were initially examined by reflected and transmitted light microscopy to characterize the mineralogy, textures, and parageneses. Eight sections of quartz from samples of the two hydrothermal mineralization stages (main stage and late stage) and six sections of sulfide from samples of three hydrothermal stages (early stage, main stage, and late stage) were selected. The analytical methods of S-H-O-C-S$\mathrm{Pb}$ isotopes and fluid inclusions are cited from our previous publication [20] and are described briefly in the following sections.

4.2. Sulfur Isotope Analysis. In situ sulfur isotope analyses on sulfide minerals were conducted by the LA-MC-ICP-MS method. The diameter of the laser beam was set to $33 \mu \mathrm{m}$ with a laser repetition rate of $10 \mathrm{~Hz}$, and the ablation process was set to last for $40 \mathrm{~s}$ [20]. The standard-sample-standard bracketing method was used to calibrate the mass bias of the instrument and the fractionation of isotopes. The sphalerite standard NBS-123 $\left(\delta^{34} \mathrm{~S}_{\mathrm{V}-\mathrm{CDT}}=17.0 \%\right.$, [21] $)$ and natural pyrite standard WS-1 (in-house standard, $\delta^{34} \mathrm{~S}_{\mathrm{V}-\mathrm{CDT}}=$ $0.9 \%$, [22]) were used as the external standard. The $\delta^{34}$ $\mathrm{S}_{\mathrm{V}-\mathrm{CDT}}$ value of sphalerite was calibrated by NBS-123 and pyrite, galena, and chalcopyrite by WS-1. The $\delta^{34} \mathrm{~S}_{\mathrm{V}-\mathrm{CDT}}$ value of NBS-123 calibrated through the WS- 1 is $17.0 \pm 0.5$ $\%$, which indicated that the matrix effect of different sulfides is not obvious [20]. The sulfur isotope data are reported in delta notation $(\%)$ relative to Vienna Canyon Diablo Troilite (V-CDT). The analytical precision $(1 \sigma)$ was about $\pm 0.1 \%$ and detailed analytical conditions and procedures can be seen in [20-23].

4.3. H-O-C Isotope Analysis. Hydrogen and oxygen isotopes of quartz and carbon and oxygen isotopes of calcite were measured at the Institute of Mineral Resources, Chinese Academy of Geological Sciences. Hydrogen isotope ratios of water decrepitated from quartz-hosted inclusions were measured by the zinc reduction method at $410^{\circ} \mathrm{C}$ and analyzed using a MAT 253 mass spectrometer. Oxygen isotope ratios of quartz were measured followed the $\mathrm{BrF}_{5}$ method described by [24]. The oxygen and hydrogen isotope data are reported in standard $\delta$ notion (\%o) relative to the Vienna Standard Mean Ocean Water (V-SMOW). The analytical precision $(2 \sigma)$ is estimated to be better than $\pm 2 \%$ or for $\delta \mathrm{D}$ and $\pm 0.2 \%$ for $\delta^{18} \mathrm{O}$. Carbon and oxygen isotope ratios of calcite were measured after the calcite reaction with pure phosphoric acid to produce $\mathrm{CO}_{2}$. The analytical precisions $(2 \sigma)$ are $\pm 0.2 \%$ for $\delta^{13} \mathrm{C}$ and $\delta^{18} \mathrm{O}$. Carbon and oxygen isotope compositions are reported relative to $\mathrm{V}$-PDB, and $\delta^{18} \mathrm{O}_{\mathrm{V}-\mathrm{SMOW}}$ values are calculated using the following equation: $\delta^{18} \mathrm{O}_{\mathrm{V}-\mathrm{SMOW}}=$ $1.03092 \times \delta^{18} \mathrm{O}_{\mathrm{V}-\mathrm{PDB}}+30.92[25]$.

4.4. Lead Isotope Analysis. The lead isotopic compositions of three pyrites, one sphalerite, one galena, one pyrrhotite, one bismuthine samples, and two granodiorite samples have been analyzed on a Neptune Plus MC-ICP-MS at Wuhan Center of China Geology Survey. Sulfide samples were completed dissolved by $\mathrm{HNO}_{3}$, rock samples by $\mathrm{HNO}_{3}+\mathrm{HF}$ and purified by cation-exchange resin using the same purification procedures. The standard errors of data were calculated by the software of Neptune through analyses of 40 data types (4 blocks, 10 cycles) [20]. In the $200 \mathrm{ppb} \mathrm{Pb}$ solution, the signal intensity of ${ }^{208} \mathrm{~Pb}$ was approximately $6 \mathrm{~V}$, whereas in the blank solution the ${ }^{208} \mathrm{~Pb}$ signal was approximately $20 \mathrm{mV}$. Standard Tl NBS997 $\left({ }^{203} \mathrm{Tl} /{ }^{205} \mathrm{Tl}=0.418922\right)$ is added to 


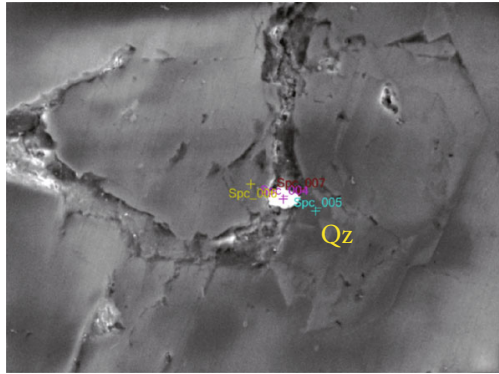

$-10 \mu \mathrm{m}$

(a)

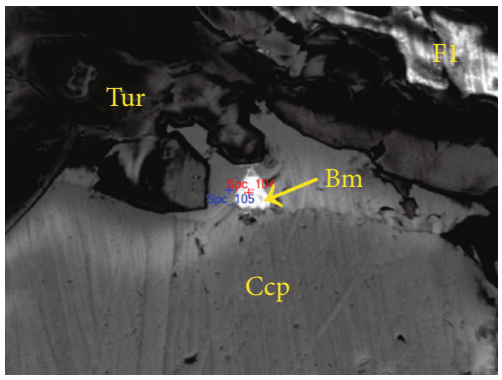

$-20 \mu \mathrm{m}$

(c)

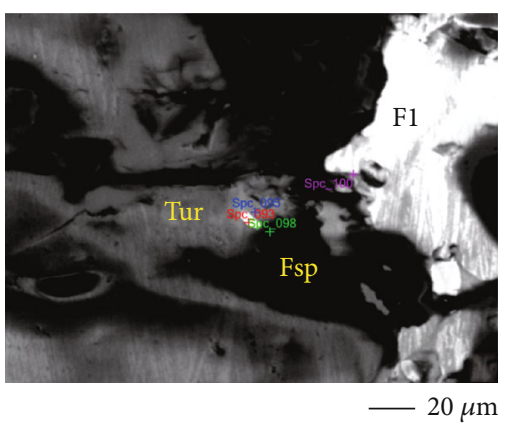

(e)

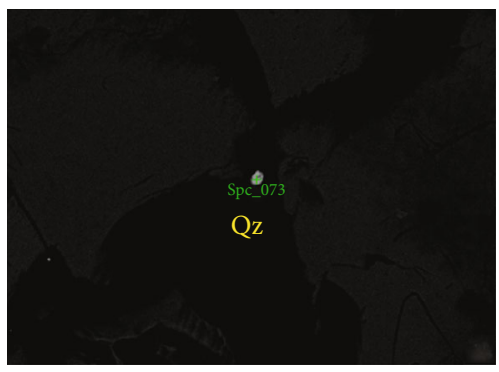

$-10 \mu \mathrm{m}$

(g)

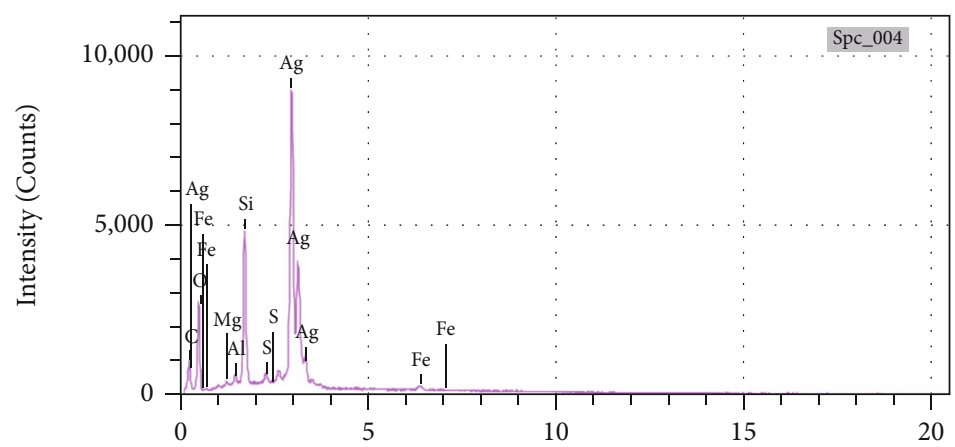

(b)

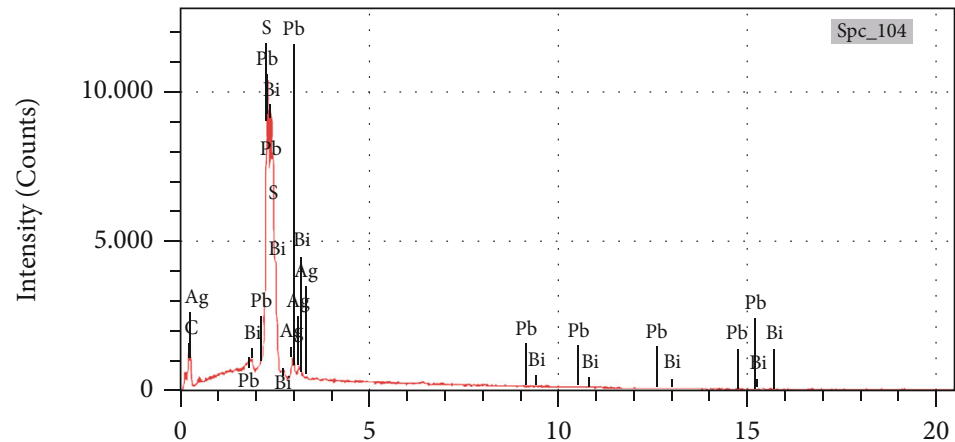

(d)

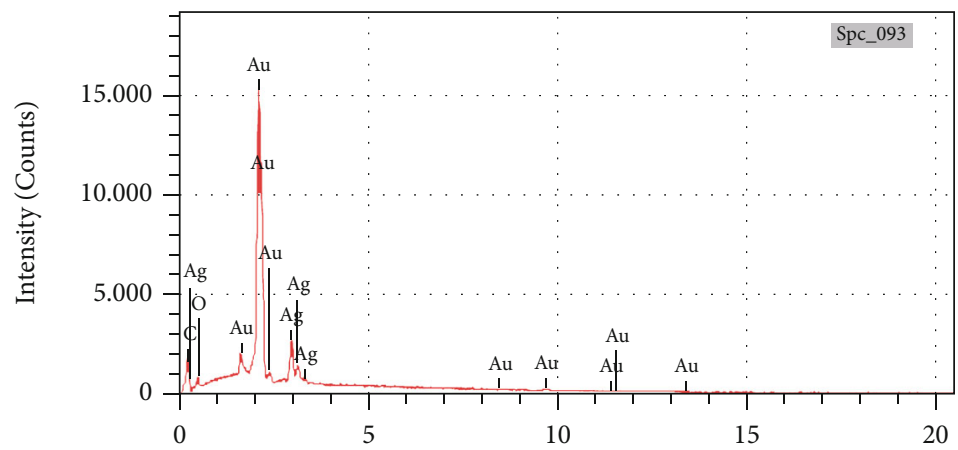

(f)

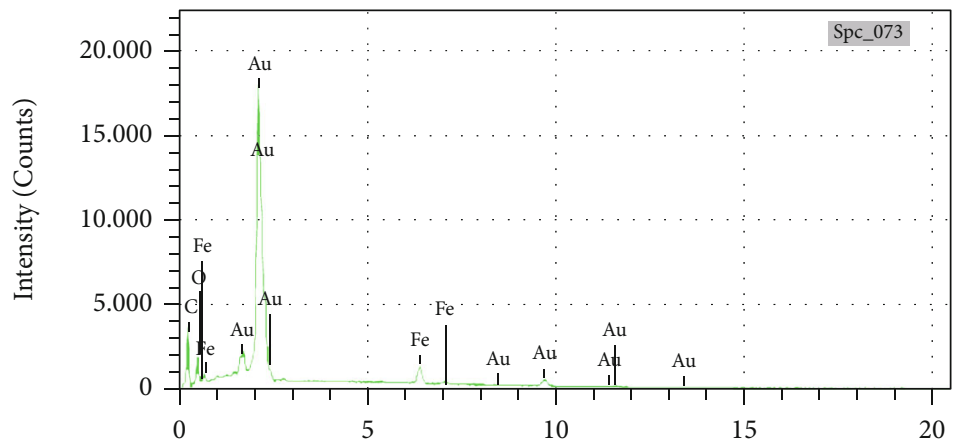

(h)

Figure 5: Continued. 


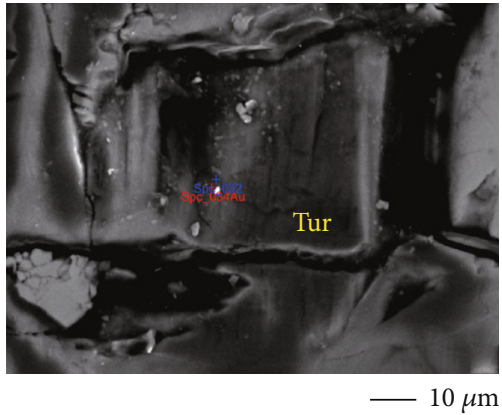

(i)

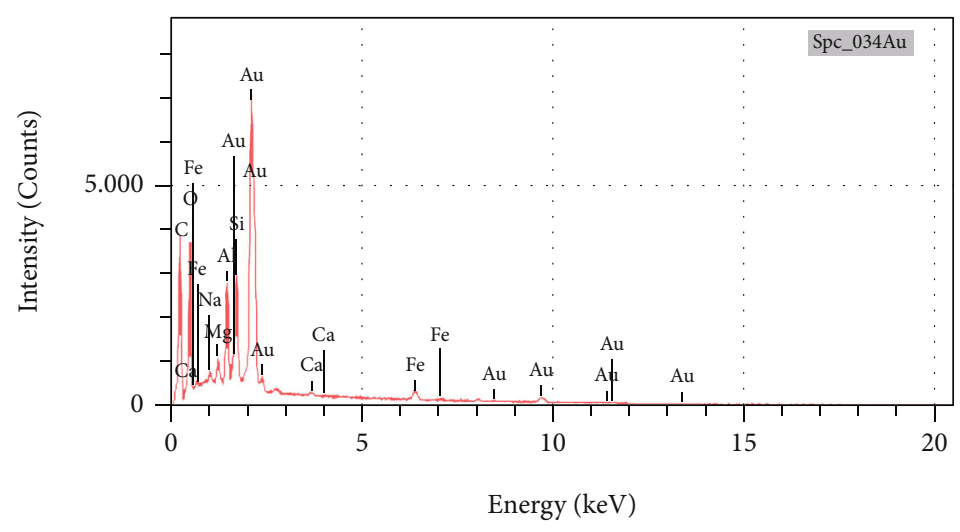

(j)

FIgURE 5: Electric scanning images and spectral images of Au-bearing and Ag-bearing minerals of Xinmin deposit. (a) Nature silver in the fissure of quartz. (b) Spectral image of silver in the quartz. (c) Sliver-bearing bismuthinite enclosed by chalcopyrite. (d) Spectral image of silver-bearing bismuthinite. (e) Silver, gold-bearing mineral in the tourmaline. (f) Spectral image of silver, gold-bearing mineral in the tourmaline. (g) Nature gold in the fissure of quartz. (h) Spectral image of gold in the quartz. (i) Nature gold in the tourmaline. (j) Spectral image of gold in the tourmaline. Mineral abbreviations (after [19]): Bm: bismuthinite; Ccp: chalcopyrite; Fl: fluorite; Fsp: feldspar; Qz: quartz; Tur: tourmaline.

sample solution for correcting mass bias of $\mathrm{Pb}$ isotope ratios, with analytical reproducibility of $0.1 \%(2 \sigma)$ for ${ }^{206} \mathrm{~Pb} /{ }^{204} \mathrm{~Pb}$, ${ }^{207} \mathrm{~Pb} /{ }^{204} \mathrm{~Pb}$, and $0.2 \%(2 \sigma)$ for ${ }^{208} \mathrm{~Pb} /{ }^{204} \mathrm{~Pb}$, and detailed analytical conditions and procedures can be seen in $[20,26]$.

4.5. Fluid Inclusion Studies. Eleven double-polished thin sections (about $200 \mu \mathrm{m}$ thick) associated with two hydrothermal stages were examined under transmitted light to identify the phase, shape, size, and distribution [20]. Eight doublepolished thin sections were selected for microthermometric measurements and laser Raman spectroscopic analyses.

Fluid inclusion petrographic studies were carried out in Wuhan Center, China Geology of Survey. Microthermometric measurements were conducted by a Linkam THMSG 600 heating-freezing stage (from $-196^{\circ} \mathrm{C}$ to $550^{\circ} \mathrm{C}$ ) mounted on a Lecia DM2700P microscope [20]. The heating-freezing stage calibration is carried out at $-56.6^{\circ} \mathrm{C}, 0.0^{\circ} \mathrm{C}$, and $374.1^{\circ} \mathrm{C}$ using the standard of synthetic FIs supplied by FLUID INC, USA. During heating/freezing runs, the heating/freezing rate was generally constrained at 0.2 $5^{\circ} \mathrm{C} / \mathrm{min}$ but was reduced to $<0.2^{\circ} \mathrm{C} / \mathrm{min}$ near the phase transformation [20]. Ice-melting temperatures were obtained at a heating rate of less than $0.1^{\circ} \mathrm{C} / \mathrm{min}$ and homogenization temperature at a rate of $<1^{\circ} \mathrm{C} / \mathrm{min}$. Salinities were calculated using the equation of [27] for aqueous inclusions and $\mathrm{NaCl}$ aqueous inclusions. Densities $\left(\mathrm{g} / \mathrm{cm}^{3}\right)$ and pressures were estimated using the equation of [28-30].

Laser Raman spectroscopic analyses of FIs were carried out at the State Key Laboratory of Geological Processes and Mineral Resources, China University of Geosciences, Wuhan, using a DXR laser Raman spectrometer manufactured by the Thermo Fisher Scientific Company, with a $54.5 \mathrm{~nm} \mathrm{Ar}^{+}$ion laser as the excitation source operating at $20 \mathrm{~mW}$ [20]. The exposure time was 20-40 s and ranged from 50 to $3500 \mathrm{~cm}^{-1}$. Spectrograph aperture was defined as $50 \mu \mathrm{m}$ pinhole. Instrumental settings were kept constant during all analyses [20].

\section{Results}

5.1. Sulfur Isotopic Compositions of Sulfides. Sulfides from the Xinmin deposit displayed a narrow range of $\delta^{34} S$ values (Table 1, Figure 6). The $\delta^{34} \mathrm{~S}$ values of euhedral pyrite (PyI) in the veins of country rock show a range from -1.9 to $1.2 \%$ ( $n=8$, avg. $0.2 \%$ ). The $\delta^{34} \mathrm{~S}$ values of anhedral sulfides (pyrrhotite, pyrite, sphalerite, chalcopyrite, galena, and bismuthine) in the main ore stage show a range from 1.2 to $1.7 \%$ o $(n=4$, avg. $1.3 \%$ ),-0.8 to $1.9 \%$ o $(n=7$, avg. $0.2 \%$ o), -1.0 to $0.6 \%$ o $(n=8$, avg. $-0.1 \%$ o), -1.4 to $0.2 \%$ o $(n=8$, avg. $-0.6 \%$ o), -3.3 to $-1.9 \%$ o $(n=4$, avg. $-2.9 \%$ o), and -3.2 to $-1.4 \%$ o ( $n=8$, avg. $-2.5 \%$ ), respectively. The isotopic composition of $\mathrm{H}_{2} \mathrm{~S}$ in ore fluids equilibrated with PyI was calculated using a temperature of $350^{\circ} \mathrm{C}$, and PoII, PyII, SpII, CcpII, GnII, and BmII using a temperature of $250^{\circ} \mathrm{C}$, and the fractionation equations of [31]. The resulting $\delta^{34} \mathrm{~S}_{\mathrm{H} 2 \mathrm{~S}}$ values range from $-2.9 \%$ o to $+1.9 \%$ o $(n=46$, avg. $-0.6 \%$ o $)$.

As a whole, the average $\delta^{34} \mathrm{~S}$ values of different sulfide minerals in the Xinmin deposit show a decreasing sequence of $\delta^{34} \mathrm{~S}_{\mathrm{Py}}(0.2 \% 0)>\delta^{34} \mathrm{~S}_{\mathrm{Sp}}(-0.1 \% \mathrm{o})>\delta^{34} \mathrm{~S}_{\mathrm{Ccp}}(-0.6 \% 0)>\delta^{34}$ $\mathrm{S}_{\mathrm{Gn}}\left(-2.9 \%\right.$ ), which is consistent with the $\delta^{34} \mathrm{~S}$ enrichment at the equilibrium conditions of sulfur isotope fractionation [32]. Hence, the sulfur isotopic equilibrium temperatures $\left(161^{\circ} \mathrm{C}\right.$ to $273^{\circ} \mathrm{C}$ ) of mineral pairs (sphalerite and galena, Figure 7), calculated using the fractionation equation, record their formation temperatures.

5.2. H-O Isotopes of Quartz and C-O Isotopes of Calcite. The $\delta \mathrm{D}$ values of fluid inclusion water in quartz range from $-45 \%$ o to $-52 \%$ o (Table 2 ). The $\delta^{18} \mathrm{O}$ values of quartz range from $+12.5 \%$ o to $+14.3 \%$ o (Table 2 ). The calculated $\delta^{18} \mathrm{O}$ values of water vary from $+6.7 \%$ o to $+8.5 \%$ and $+3.0 \%$ o to $4.8 \%$, respectively, using the equilibrium fractionation equation of quartz water at $350^{\circ} \mathrm{C}$ and $250^{\circ} \mathrm{C}$ [32]. On a plot of $\delta \mathrm{D}$ 
TABLE 1: Sulfur isotope data of sulfide minerals from the Xinmin deposit.

\begin{tabular}{|c|c|c|c|c|}
\hline Number & Sample ID & Mineral & $\delta^{34} \mathrm{~S}_{\mathrm{V}-\mathrm{CDT}}(\% \mathrm{o})$ & $\delta^{34} \mathrm{~S}_{\mathrm{H} 2 \mathrm{~S}}(\%)$ \\
\hline 1 & XM-24-1 & PyI & -0.3 & -1.3 \\
\hline 2 & XM-7-4 & PyI & 0.5 & -0.5 \\
\hline 3 & XM-33-4 & PyI & -1.9 & -2.9 \\
\hline 4 & XM-13-8 & PyI & 1.2 & 0.1 \\
\hline 5 & XM-10-1 & PyI & 0.7 & -0.3 \\
\hline 6 & XM-10-2 & PyI & 0.8 & -0.3 \\
\hline \multirow[t]{2}{*}{7} & XM-10-3 & PyI & 0.3 & -0.7 \\
\hline & Average & & 0.2 & -0.8 \\
\hline 8 & XM-7-2 & BmII & -2.3 & -0.4 \\
\hline 9 & XM-7-3 & BmII & -2.8 & -0.9 \\
\hline 10 & XM-1-1 & BmII & -3.1 & -1.2 \\
\hline 11 & XM-1-5 & BmII & -3.2 & -1.4 \\
\hline 12 & XM-33-9 & BmII & -2.5 & -0.6 \\
\hline 13 & XM-33-10 & BmII & -2.4 & -0.5 \\
\hline 14 & XM-13-2 & BmII & -2.4 & -0.5 \\
\hline \multirow[t]{2}{*}{15} & XM-13-7 & BmII & -1.4 & 0.5 \\
\hline & Average & & -2.5 & -0.6 \\
\hline 16 & XM-1-3 & CcpII & -0.2 & -0.1 \\
\hline 17 & XM-1-8 & CcpII & 0.2 & 0.4 \\
\hline 18 & XM-24-2 & CcpII & -0.6 & -0.4 \\
\hline 19 & XM-33-5 & CcpII & -0.7 & -0.5 \\
\hline 20 & XM-33-9 & CcpII & -0.1 & 0.1 \\
\hline 21 & XM-13-3 & CcpII & -1.1 & -0.9 \\
\hline 22 & XM-13-4 & CcpIII & -1.0 & -0.8 \\
\hline \multirow[t]{2}{*}{23} & XM-13-5 & CcpIII & -1.4 & -1.2 \\
\hline & Average & & -0.6 & -0.4 \\
\hline 24 & XM-24-4 & GnII & -3.0 & -0.7 \\
\hline 25 & XM-24-5 & GnII & -3.3 & -1.0 \\
\hline 26 & XM-33-3 & GnII & -3.3 & -1.0 \\
\hline \multirow[t]{2}{*}{27} & XM-33-8 & GnII & -1.9 & 0.4 \\
\hline & Average & & -2.9 & -0.6 \\
\hline 28 & XM-1-6 & PoII & 1.3 & 0.9 \\
\hline 29 & XM-33-1 & PoII & 1.2 & 0.8 \\
\hline 30 & XM-33-7 & PoII & 1.7 & 1.3 \\
\hline \multirow[t]{2}{*}{31} & XM-13-6 & PoII & 1.3 & 0.9 \\
\hline & Average & & 1.3 & 1.0 \\
\hline 32 & XM-7-1 & PyII & 1.9 & 0.4 \\
\hline 33 & XM-1-7 & PyII & 0.6 & -0.8 \\
\hline 34 & XM-13-1 & PyII & 1.3 & -0.2 \\
\hline 35 & XM-10-1 & PyII & -0.2 & -1.7 \\
\hline 36 & XM-10-2 & PyII & -0.8 & -2.3 \\
\hline 37 & XM-10-3 & PyII & -0.8 & -2.2 \\
\hline \multirow[t]{2}{*}{38} & XM-10-4 & PyII & -0.8 & -2.2 \\
\hline & Average & & 0.2 & -1.1 \\
\hline 39 & XM-1-2 & SpII & -0.7 & -1.0 \\
\hline 40 & XM-1-4 & SpII & -0.3 & -0.7 \\
\hline 41 & XM-24-3 & SpII & -1.0 & -1.4 \\
\hline
\end{tabular}

TABle 1: Continued.

\begin{tabular}{lcccc}
\hline Number & Sample ID & Mineral & $\delta^{34} \mathrm{~S}_{\mathrm{V}-\mathrm{CDT}}(\% \mathrm{)})$ & $\delta^{34} \mathrm{~S}_{\mathrm{H} 2 \mathrm{~S}}(\% \mathrm{)})$ \\
\hline 42 & XM-24-6 & SpII & 0.1 & -0.3 \\
43 & XM-24-7 & SpII & 0.1 & -0.3 \\
44 & XM-7-5 & SpII & -0.1 & -0.5 \\
45 & XM-33-2 & SpII & 0.6 & 0.2 \\
46 & XM-33-6 & SpII & 0.5 & 0.2 \\
& Average & & -0.1 & -0.5 \\
\hline
\end{tabular}

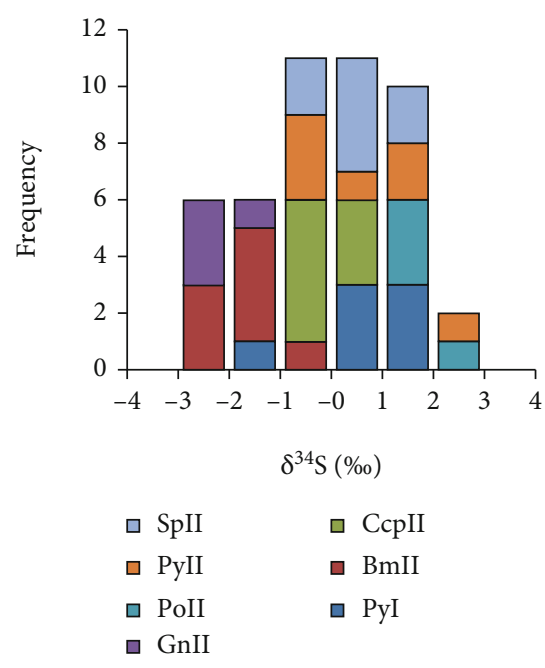

FIGURE 6: Histogram showing the distribution of measured $\delta^{34} S$ for different mineralization stages at the Xinmin deposit. Mineral abbreviations (after [19]): Bm: bismuthinite; Ccp: chalcopyrite; Gn: galena; Po: pyrrhotite; Py: pyrite; Sp: sphalerite.

vs. $\delta^{18} \mathrm{O}$, the data fall in the fields of magmatic water and peraluminous granite water (Figure 8).

The $\delta^{13} \mathrm{C}_{\mathrm{V}-\mathrm{PDB}}$ values of calcite range from $-5.8 \%$ to $+0.7 \%$ o (Table 2). The $\delta^{18} \mathrm{O}_{\mathrm{V}-\mathrm{SmOW}}$ values of calcite range from $+12.6 \%$ o to $+21.4 \%$ (Table 2, Figure 9 ). The hydrothermal fluid $\delta^{18} \mathrm{O}$ values were estimated according to the equilibrium fractionation equation of calcite-fluid at $250^{\circ} \mathrm{C}$ [36]. The $\delta^{18} \mathrm{O}_{\text {fluid }}$ values range from $+5.2 \%$ to $+13.9 \%$.

5.3. Lead Isotopic Compositions of Sulfides and Granodiorite. Sulfides (pyrrhotite, pyrite, galena, and bismuthine) and the Late Cretaceous granodiorite from the Xinmin deposit show a narrow range of lead isotopic variation (Table 3, Figure 10). The ratios of ${ }^{206} \mathrm{~Pb} /{ }^{204} \mathrm{~Pb},{ }^{207} \mathrm{~Pb} /{ }^{204} \mathrm{~Pb}$, and ${ }^{208} \mathrm{~Pb} /{ }^{204} \mathrm{~Pb}$ for sulfides change from 18.377 to $18.473,15.606$ to 16.684 , and 38.613 to 38.902 , respectively. The Late Cretaceous granodiorite shows a relatively higher ${ }^{206} \mathrm{~Pb} /{ }^{204} \mathrm{~Pb}$, ${ }^{207} \mathrm{~Pb} /{ }^{204} \mathrm{~Pb}$, and ${ }^{208} \mathrm{~Pb} /{ }^{204} \mathrm{~Pb}$ ratios, from 18.627 to 18.632 , 15.652 to 15.671 , and 38.833 to 38.902 , than some of the sulfides. The estimated primary $\mathrm{Pb}$ isotopic composition of granodiorite, according to the content of uranium, thorium, lead, and the magmatism age, is similar with most of the sulfides (Figure 10). 


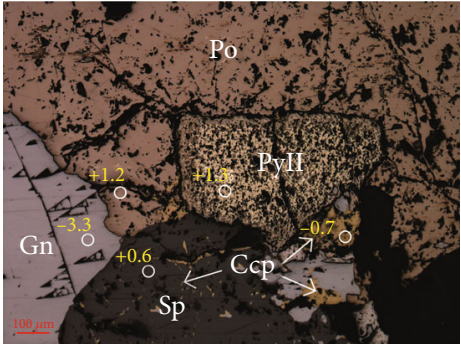

(a)

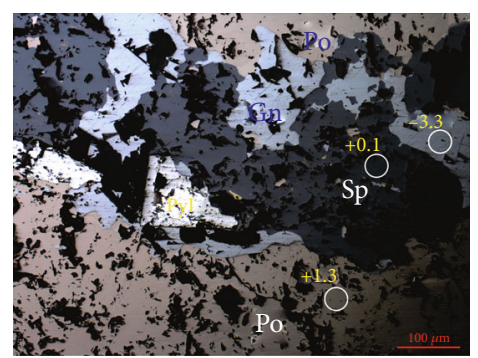

(b)

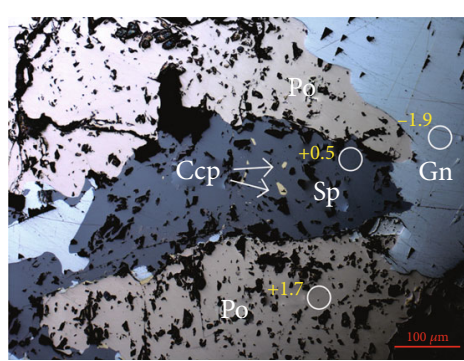

(c)

FIGURE 7: Microphotography showing the change in $\delta^{34}$ S values (\%o) of pyrrhotite, sphalerite, and galena. Mineral abbreviations (after [19]): Ccp: chalcopyrite; Gn: galena; Po: pyrrhotite; Py: pyrite; Sp: sphalerite.

TABle 2: Carbon, hydrogen, and oxygen isotope data of calcite and quartz from the Xinmin deposit.

\begin{tabular}{|c|c|c|c|c|c|c|c|c|c|}
\hline Sample ID & Mineral & $\begin{array}{c}\delta^{13} \mathrm{C}_{\mathrm{V}-\mathrm{PDB}} \\
(\% \mathrm{o})\end{array}$ & $\begin{array}{c}\delta^{18} \mathrm{O}_{\mathrm{V}-\mathrm{PDB}} \\
(\% \mathrm{o})\end{array}$ & $\begin{array}{c}\delta^{18} \mathrm{O}_{\mathrm{V}-\mathrm{SMOW}} \\
(\% \mathrm{o})\end{array}$ & $\begin{array}{l}\delta^{18} \mathrm{O}_{\mathrm{V}-\text { SMOWfluid }} \\
(\%) T=250^{\circ} \mathrm{C}\end{array}$ & $\begin{array}{l}\delta \mathrm{D} \\
(\%)\end{array}$ & $\begin{array}{c}\delta^{18} \mathrm{O}_{\mathrm{V}-\mathrm{SMOW}} \\
(\% \mathrm{o})\end{array}$ & $\begin{array}{l}\delta^{18} \mathrm{O}_{\mathrm{V}-\text { SMOWfluid }} \\
(\%) \mathrm{T}=250^{\circ} \mathrm{C}\end{array}$ & $\begin{array}{l}\delta^{18} \mathrm{O}_{\mathrm{V}-\mathrm{SMOWfluid}} \\
\left(\% \text { o) } \mathrm{T}=350^{\circ} \mathrm{C}\right.\end{array}$ \\
\hline $16 \mathrm{XM}-1$ & Calcite & 0.2 & -9.3 & 21.4 & 13.9 & & & & \\
\hline $16 \mathrm{XM}-6$ & Calcite & -5.8 & -17.7 & 12.6 & 5.2 & & & & \\
\hline $16 \mathrm{XM}-14$ & Calcite & 0.7 & -11.4 & 19.2 & 11.7 & & & & \\
\hline $16 \mathrm{XM}-15$ & Calcite & -3.4 & -16.1 & 14.4 & 6.9 & & & & \\
\hline $16 \mathrm{XM}-4$ & Quartz & & & & & -50 & 13.2 & 3.8 & 7.4 \\
\hline 16XM-09 & Quartz & & & & & -50 & 13.4 & 3.9 & 7.6 \\
\hline 16XM-06 & Quartz & & & & & -45 & 12.5 & 3.0 & 6.7 \\
\hline $16 \mathrm{XM}-01$ & Quartz & & & & & -52 & 14.3 & 4.8 & 8.5 \\
\hline
\end{tabular}

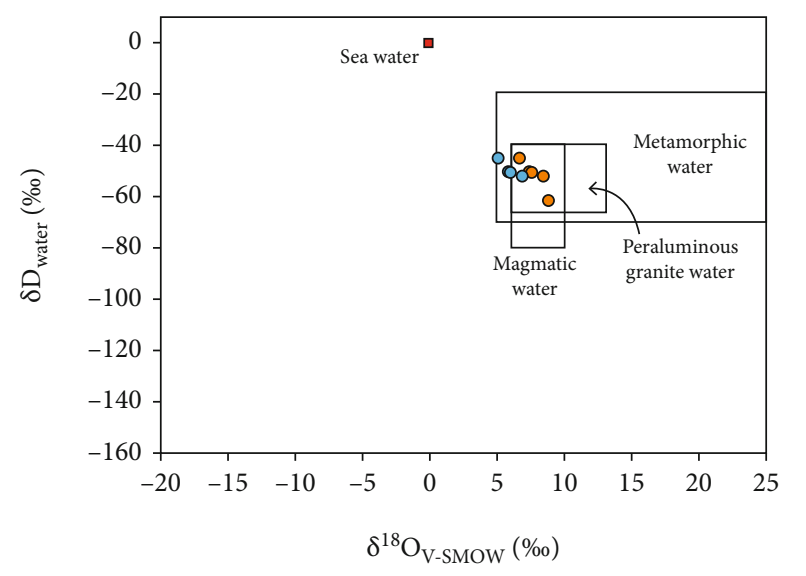

- $350^{\circ} \mathrm{C}$

- $300^{\circ} \mathrm{C}$

Figure 8: Calculated oxygen and hydrogen isotope compositions of fluids in equilibrium with quartz from the Xinmin deposit. The fields for metamorphic fluids are after [33], magmatic and peraluminous granite fields from $[34,35]$.

\subsection{Fluid Inclusions}

5.4.1. Type and Occurrence of Fluid Inclusions. Petrographic study of fluid inclusions was conducted with an optical microscope. All samples contain abundant primary and pseudosecondary inclusions. In general, the primary FIs were identified by their occurrence in crystal growth zones

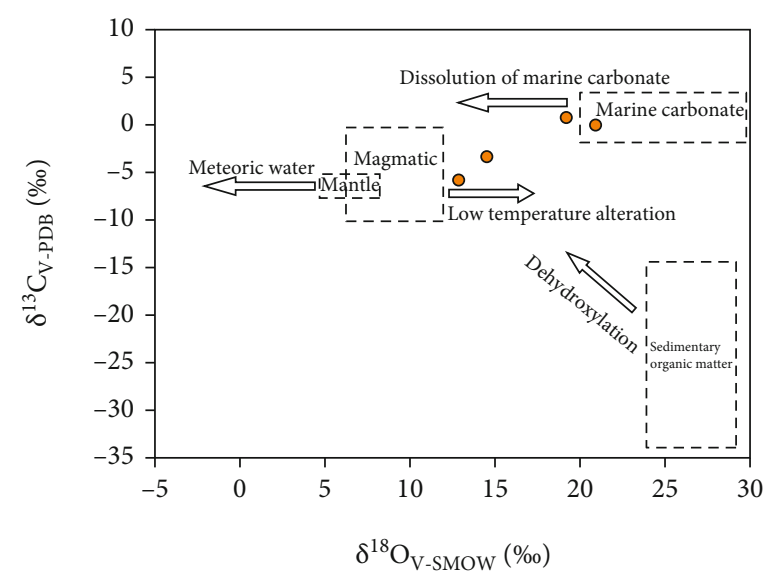

Figure 9: $\delta^{18} \mathrm{O}_{\mathrm{V}-\mathrm{SMOW}}$ versus $\delta^{13} \mathrm{C}_{\mathrm{V}-\mathrm{PDB}}$ diagram of carbonate from the Xinmin deposit (after [37]).

of the host mineral or as the isolated inclusions, while secondary FIs present as penetrating crystal boundaries (Figures 11(a)-11(c)). These FIs vary from $4 \mu \mathrm{m}$ to over $25 \mu \mathrm{m}$; most of them are $8 \mu \mathrm{m}$ to over $20 \mu \mathrm{m}$ in size. Most FIs only have liquid and vapour two phases; minor FIs of quartz from the main ore stage has salty daughter mineral (Figure 11(d)).

5.4.2. Laser Raman Spectroscopy. Laser Raman spectroscopy analyses were carried out to constrain the fluid inclusion 
TABLE 3: Lead isotope data of sulfides and granodiorite rocks from the Xinmin deposit.

\begin{tabular}{lccccccccc}
\hline Sample ID & Mineral & ${ }^{206} \mathrm{~Pb} /{ }^{204} \mathrm{~Pb}$ & $2 \sigma$ & ${ }^{207} \mathrm{~Pb} /{ }^{204} \mathrm{~Pb}$ & $2 \sigma$ & ${ }^{208} \mathrm{~Pb} /{ }^{204} \mathrm{~Pb}$ & $2 \sigma$ & $\left({ }^{206} \mathrm{~Pb} /{ }^{204} \mathrm{~Pb}\right)_{\mathrm{i}}$ & $\left({ }^{207} \mathrm{~Pb} /{ }^{204} \mathrm{~Pb}\right)_{\mathrm{i}}\left({ }^{208} \mathrm{~Pb} /{ }^{204} \mathrm{~Pb}\right)_{\mathrm{i}}$ \\
\hline XM-1 & Pyrite & 18.460 & 0.003 & 15.684 & 0.003 & 38.902 & 0.007 & & \\
XM-1 & Bismuthinite & 18.454 & 0.003 & 15.675 & 0.002 & 38.844 & 0.007 & & \\
$\mathrm{XM}-12$ & Pyrite & 18.473 & 0.004 & 15.661 & 0.004 & 38.797 & 0.01 & & \\
$\mathrm{XM}-24$ & Pyrite & 18.377 & 0.004 & 15.606 & 0.004 & 38.613 & 0.008 & & \\
$\mathrm{XM}-24$ & Sphalerite & 18.38 & 0.005 & 15.667 & 0.007 & 38.892 & 0.017 & & \\
XM-24 & Galena & 18.378 & 0.002 & 15.613 & 0.002 & 38.637 & 0.004 & & 15.665 \\
XM-33 & Pyrrhotite & 18.428 & 0.003 & 15.616 & 0.003 & 38.674 & 0.004 & & 38.787 \\
XM-31A & Granodiorite & 18.632 & 0.001 & 15.671 & 0.001 & 38.902 & 0.004 & 18.533 & 15.646 \\
XM-31B & Granodiorite & 18.627 & 0.001 & 15.652 & 0.001 & 38.833 & 0.003 & 18.528 & 38.718 \\
\hline
\end{tabular}

$\left({ }^{206} \mathrm{~Pb} /{ }^{204} \mathrm{~Pb}\right)$ : calculated initial ${ }^{206} \mathrm{~Pb} /{ }^{204} \mathrm{~Pb} ;\left({ }^{207} \mathrm{~Pb} /{ }^{204} \mathrm{~Pb}\right)$ : calculated initial ${ }^{207} \mathrm{~Pb} /{ }^{204} \mathrm{~Pb} ;\left({ }^{208} \mathrm{~Pb} /{ }^{204} \mathrm{~Pb}\right)$ : calculated initial ${ }^{208} \mathrm{~Pb} /{ }^{204} \mathrm{~Pb}$; the age of granodiorite used for calculation is $96.5 \mathrm{Ma}$, and the $\mathrm{U}$, Th, Pb contents of XM-31A and XM-31B are 8.4, 22, $71 \mathrm{ppm}$ and 5.2, 19, 72.8 ppm, respectively.

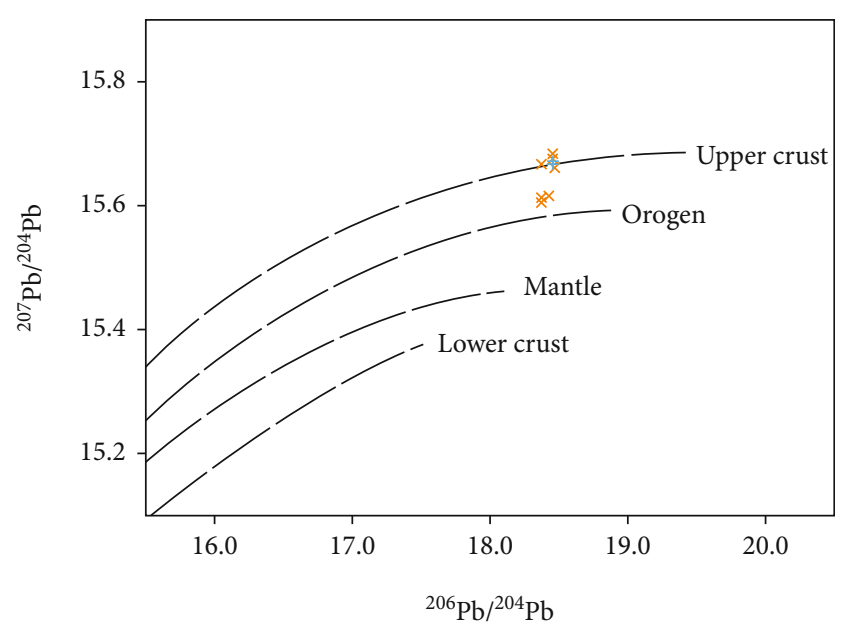

(a)

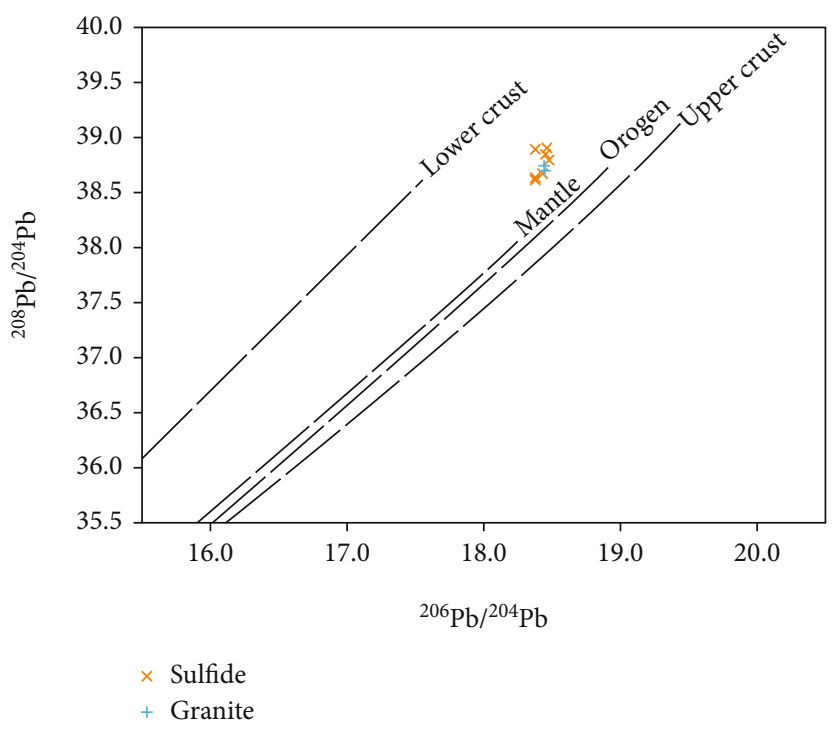

(b)

Figure 10: Plot of ${ }^{207} \mathrm{~Pb} /{ }^{204} \mathrm{~Pb}$ versus ${ }^{206} \mathrm{~Pb} /{ }^{204} \mathrm{~Pb}$ (a) and ${ }^{208} \mathrm{~Pb} /{ }^{204} \mathrm{~Pb}$ versus ${ }^{206} \mathrm{~Pb} /{ }^{204} \mathrm{~Pb}$ (b) for the sulfides and granodiorite from the Xinmin deposit.

compositions of representative samples from two hydrothermal stages. The results show that minor $\mathrm{CO}_{2}$ was observed in the main stage quartz (Figure 12(a)), whereas the gas phase of the two-phase fluid inclusions in the late stage vein quartz contains minor $\mathrm{CO}_{2}$ with the peak of 1283 and $1386 \mathrm{~cm}^{-1}$ and also $\mathrm{CH}_{4}$ with the peak of $2915 \mathrm{~cm}^{-1}$ (Figures 12(a)$12(\mathrm{c})$ ).

5.4.3. Microthermometry. The microthermometric results, calculated salinities and densities of FIs of the main ore stage and late stage, are shown in Table 4 and Figures 13 and 14. In the main ore stage, these FIs yield the ice-melting temperature $\left(T_{\mathrm{m} \text {-ice }}\right)$ from $-19.3^{\circ} \mathrm{C}$ to $-1.6^{\circ} \mathrm{C}$, and their salinities are estimated to be 2.7 to $50.7 \mathrm{wt} \% \mathrm{NaCl}$ equivalent by the equation of [27]. Except 4 fluid inclusions, most FIs homogenized into liquid phase at temperature $\left(T_{h}\right)$ of $205^{\circ} \mathrm{C}$ to $485^{\circ} \mathrm{C}$.
Their densities are acquired, fluctuating from 0.55 to $1.09 \mathrm{~g} / \mathrm{cm}^{3}$. In the late stage, ice-melting temperature $\left(T_{\mathrm{m} \text {-ice }}\right)$ of FIs range from $-5.7^{\circ} \mathrm{C}$ to $-0.1^{\circ} \mathrm{C}$, with corresponding salinities from 0.18 to 8.81 wt. $\% \mathrm{NaCl}$ equivalent. Except 1 fluid inclusion, most FIs homogenized into liquid phase at temperature $\left(T_{h}\right)$ of $116^{\circ} \mathrm{C}$ to $300^{\circ} \mathrm{C}$, and their densities are 0.76 to $0.98 \mathrm{~g} / \mathrm{cm}^{3}$ (Table 4 ).

\section{Discussion}

6.1. Source of Ore Fluids. Gold, silver, and copper are transported predominantly by sulfur ligands in reduced and mesothermal aqueous-carbonic solutions [31, 32]. The sulfur isotopic composition of sulfides can, therefore, provide valuable information on the source, transport, and precipitation 


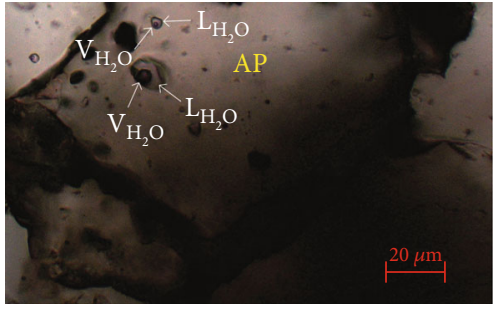

(a)

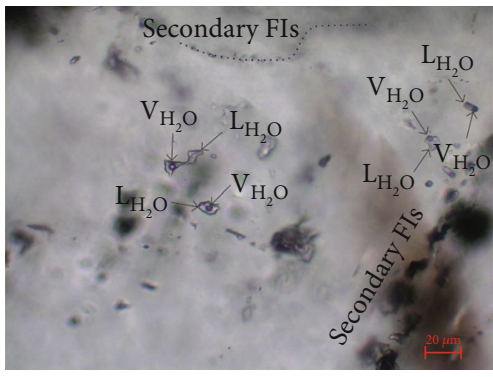

(c)

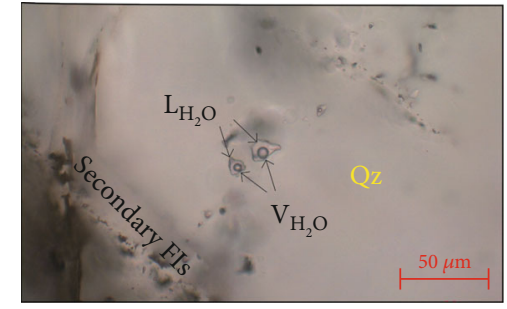

(b)

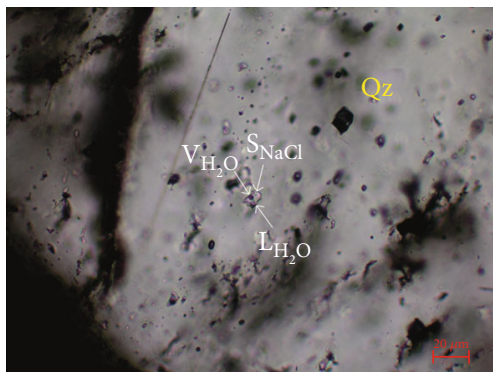

(d)

FIgURE 11: Photomicrographs showing the types and distribution of fluid inclusions observed in the Xinmin deposit. (a) Primary aqueous inclusions in the main stage apatite. (b) Primary aqueous inclusions and secondary aqueous inclusions in the main stage quartz. (c) Primary aqueous inclusions and secondary aqueous inclusion in the late stage quartz. (d) Primary daughter mineral-bearing inclusions in the main stage quartz. Mineral abbreviations (after [19]): Ap: apatite; Qz: quartz.

of gold, silver, and copper and, thus, on the genesis of the polymetallic deposits.

Our in situ sulfur isotope analyses of pyrite, chalcopyrite, pyrrhotite, galena, sphalerite, and bismuthinite reveal a narrow $\delta^{34} S$ range from $-3.3 \%$ to $+1.9 \%$. It has been proposed that the major controls on $\delta^{34} \mathrm{~S}$ values of sulfide minerals are the sulfur source, temperature, $\mathrm{pH}$, and oxygen fugacity $\left(f_{\mathrm{O} 2}\right)$ [38]. The sharp change of $\mathrm{pH}$ and the oxygen fugacity $\left(f_{\mathrm{O} 2}\right)$ was not found in the Xinmin deposit according to the mineral assemblages. The temperatures of the main ore stage and late stage have been constrained by our microthermomeric data to between $485^{\circ} \mathrm{C}$ to $205^{\circ} \mathrm{C}$ and $300^{\circ} \mathrm{C}$ to $116^{\circ} \mathrm{C}$, respectively, displaying an obvious decreasing trend. The $\delta^{34} \mathrm{~S}$ values of the hydrothermal fluid can be estimated from the measured $\delta^{34} \mathrm{~S}$ of sulfides, assumed oxygen fugacity $\left(f_{\mathrm{O} 2}\right)$, and temperature conditions [31]. The estimated $\delta^{34}$ $\mathrm{S}_{\text {fluid }}$ values also display a narrow range from $-2.9 \%$ to $+1.9 \%$. Such sulfur isotopic composition and variation of $\delta^{34} \mathrm{~S}_{\text {fluid }}$ is consistent with a single homogeneous sulfur source, such as magmatic (mostly between $-3 \%$ and $1 \%$, [39]) and mantle sulfur (around 0\%o, [31]). Considering the Pingtianshan granite pluton and Longtoushan subvolcanic granitic porphyry occurred in the Xinmin deposit, the most reasonable sulfur source is probably magmatic sulfur which was derived from the granitic magma.

The relatively uniform $\mathrm{Pb}$ isotopic composition of sulfide from Xinmin (Figure 10) suggests a single $\mathrm{Pb}$ source or largescale hydrothermal circulation capable of homogenizing $\mathrm{Pb}$ from multiple reservoirs [40]. Considering the low content of uranium, thorium, lead in the sulfides, the radiogenic $\mathrm{Pb}$ is limited; therefore, the measured $\mathrm{Pb}$ isotopic ratios can represent the primary $\mathrm{Pb}$ isotopic composition. In the $\mathrm{Pb}$ $\mathrm{Pb}$ isotope diagram (Figure 10), most of the $\mathrm{Pb}$ isotopic compositions of sulfides are compatible with the $\mathrm{Pb}$ isotopic composition of the Late Cretaceous granodiorite. We therefore suggest that the principal $\mathrm{Pb}$ source for the Xinmin ore deposit was the granitic magma. It is noted that several sulfide samples show slightly lower ${ }^{207} \mathrm{~Pb} /{ }^{204} \mathrm{~Pb}$ data than the granodiorite (Figure 10), which may suggest some contribution from the country rocks.

The hydrogen-oxygen isotopic compositions of ore fluid may also imply the magmatic source characteristics (Figures 8 and 10). Oxygen isotopes of fluid in equilibrium with carbonate provide a potential approach to discern the influence of wall rocks. The $\delta^{13} \mathrm{C}_{\mathrm{V}-\mathrm{PDB}}$ and $\delta^{18} \mathrm{O}_{\mathrm{V}-\mathrm{SMOW}}$ values of calcite vein indicate a shift from magmatic source, implying the influence of marine carbonates (Figure 9). Also, the lower $\mathrm{CO}_{2} / \mathrm{H}_{2} \mathrm{O}$ molar ratio in the Xinmin ore fluid (Figure 12) is consistent with the typical character of degassed magma [41].

In summary, the $\mathrm{S}-\mathrm{H}-\mathrm{O}-\mathrm{C}-\mathrm{Pb}$ isotopes suggest that the ore fluids at Xinmin are mainly derived from a magmatic fluid. Combined with the characteristics of FIs (Figures 1114), the Xinmin deposit belongs to medium-high temperature, medium-high salinity hydrothermal deposit related to the granitic magmatism.

6.2. Metallogenic Implications. Fluid inclusions provide critical information on the ore-forming process in the hydrothermal system. In natural systems, metals in an ore-forming fluid are generally found in complexes with aqueous $\mathrm{Cl}^{-}$and $\mathrm{HS}^{-}$and are transported in the form of metal-ligand complexes [42]. Temperature is an important factor for the stability of metal complexes and the solubility of ore-forming materials. A certain degree of cooling for the ore-forming fluids could not only destroy the stability of the metal complexes but also reduce the solubility of the 


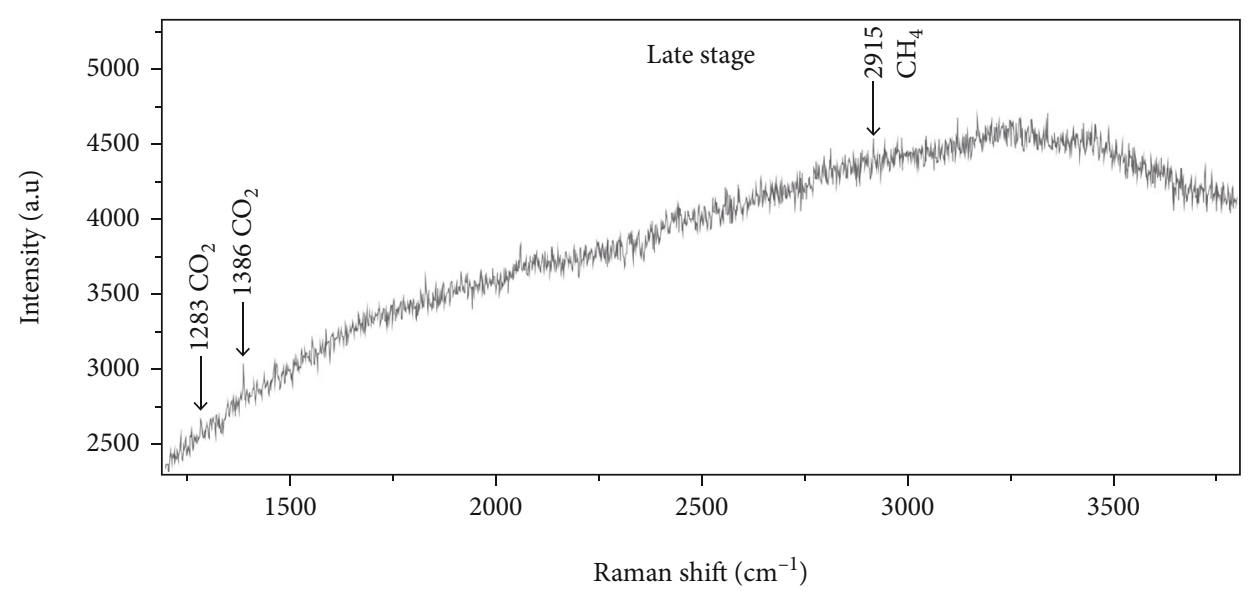

(a)

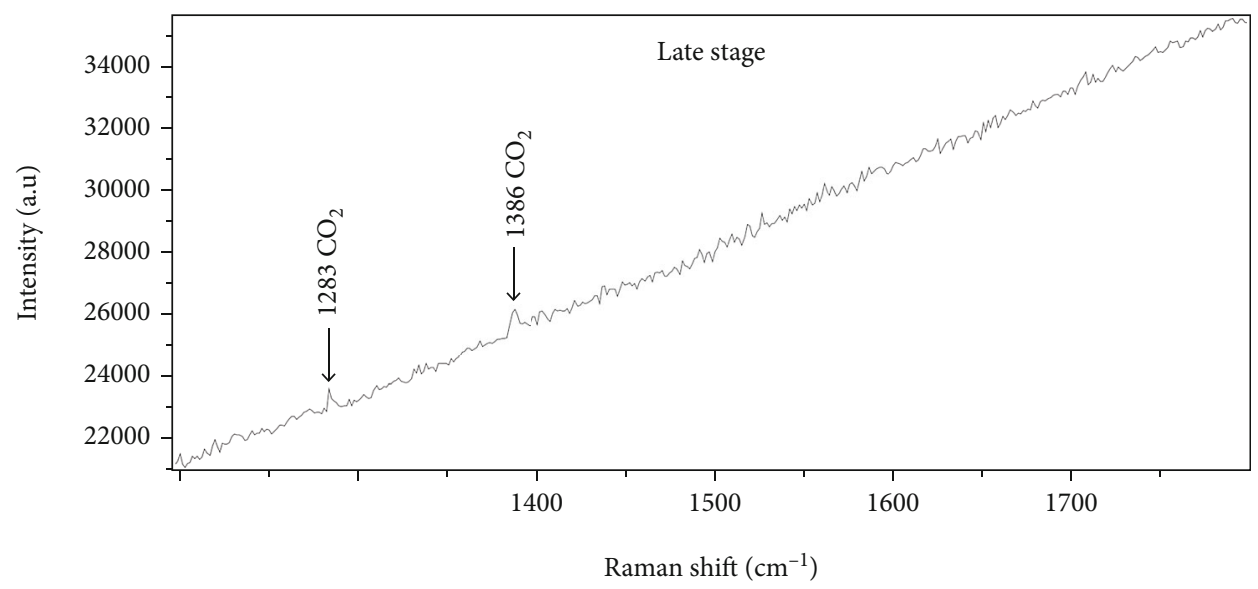

(b)

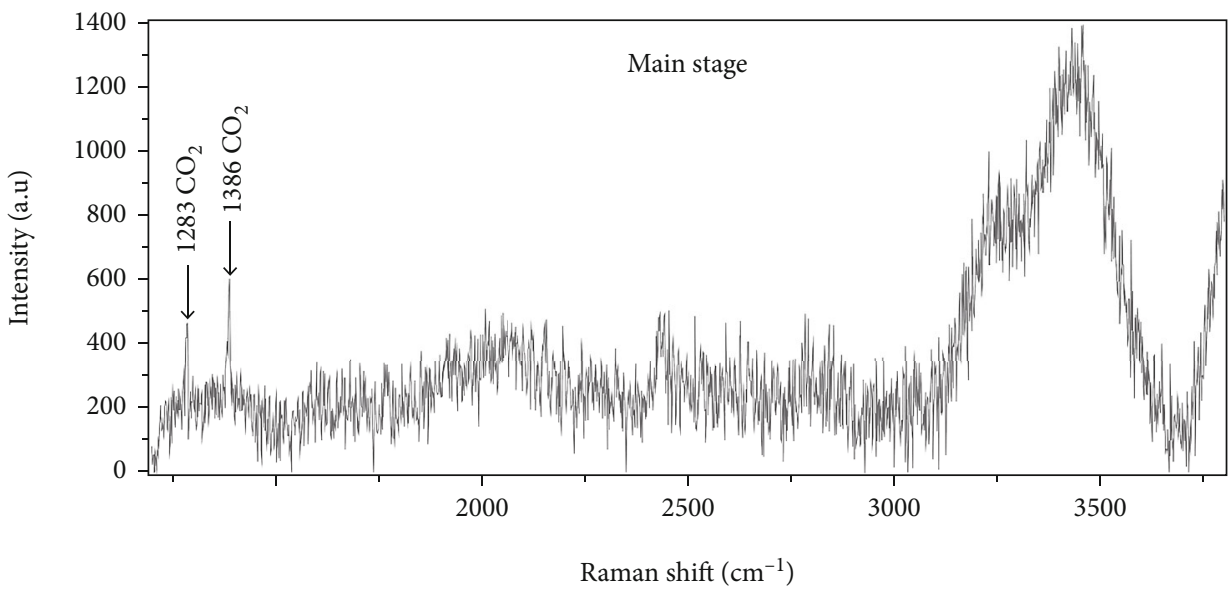

(c)

Figure 12: Laser Raman spectroscopy of different fluid inclusions in the main stage (a) and late stage (b, c).

ore metals, and it finally causes the precipitation of ore minerals from the hydrothermal system $[43,44]$. The fluid evolution diagram for the Xinmin deposit, represented by a homogenization temperature versus salinity plot, is shown in Figure 15. There is a clear trend that the homogenization temperature and salinity of the hydrothermal fluids gradually decreased from the main stage to the late stage.
The trapping pressures that we obtained also share similar variation (Figure 14(b)), dropping from 2-30 MPa to 0.4$9 \mathrm{MPa}$ during the main and late stages of the hydrothermal process. Therefore, a remarkable reduction of pressure could lead to the ascension of the magmatic fluid along fault zones to higher levels, which is consistent with the geological fact that the ore bodies mostly occurred in the EW- and NS- 
TABLE 4: Microthermometric data of fluid inclusions from the Xinmin deposit.

\begin{tabular}{lccccccc}
\hline Stage & Mineral & Number & $T_{\text {m,ice }}\left({ }^{\circ} \mathrm{C}\right)$ & $T_{h}\left({ }^{\circ} \mathrm{C}\right)$ & Salinity (wt.\% NaCl equiv.) & Density $\left(\mathrm{g} / \mathrm{cm}^{3}\right)$ & $\mathrm{Ph}(\mathrm{Mpa})$ \\
\hline Main ore stage & $\mathrm{Qz}$ & 82 & -19.2 to -1.6 & 205 to 485 & 2.7 to 50.7 & 0.55 to 1.25 & 1.69 to 30.17 \\
& $\mathrm{Ap}$ & 4 & -19.3 to -16.8 & 207 to 258 & 20.07 to 21.89 & 0.98 to 1.02 & 1.17 to 3.77 \\
Late stage & $\mathrm{Qz}$ & 73 & -5.7 to -0.1 & 116 to 300 & 0.18 to 8.81 & 0.62 to 0.98 & 0.35 to 8.6 \\
\hline
\end{tabular}

$T_{\text {m,ice }}$ : ice-melting temperature; $T_{h}$ : total homogenization temperature. All fluid inclusions, except four, homogenize into liquid phase.

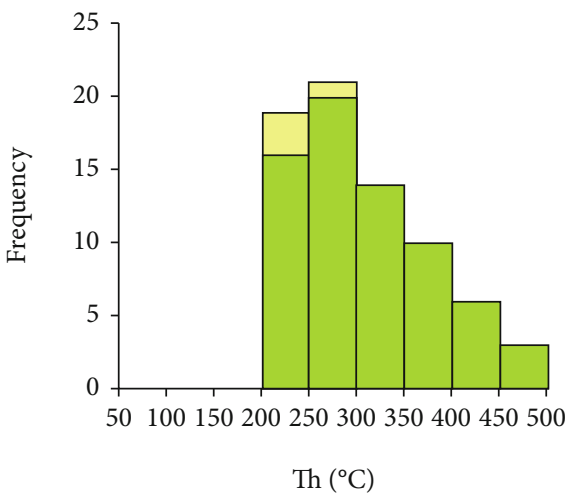

(a)

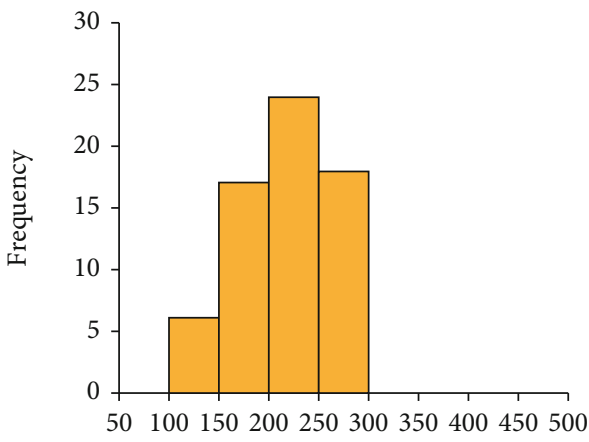

Th $\left({ }^{\circ} \mathrm{C}\right)$

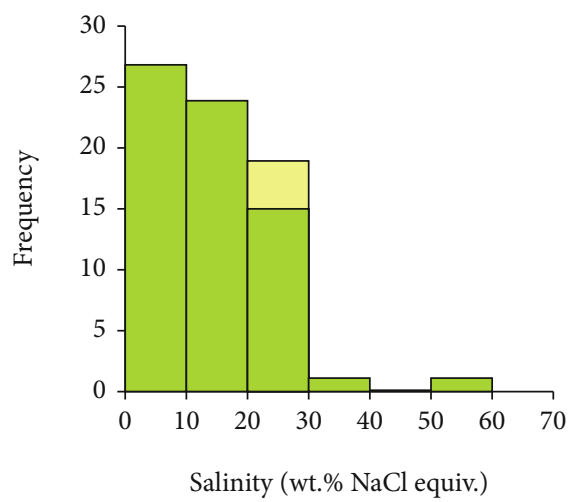

(b)

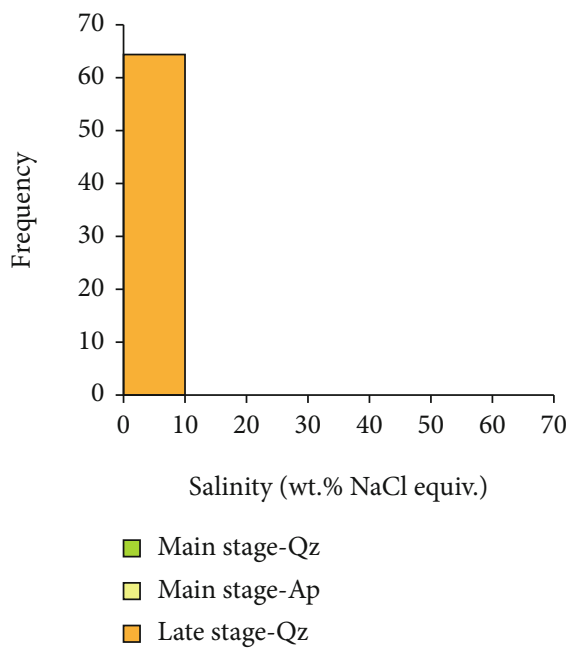

(d)

FIGURE 13: Histograms of homogenization temperatures $\left(T_{h}\right)$ and salinitites of fluid inclusions in the main ore stage (a, b) and the late stage (c, d). Ap: apatite; Qz: quartz.

trending faulted and shattered zone in the Xinmin deposit. Hence, the reduction of pressure has a significant effect on the reduction of temperature for ore-forming fluids and the formation of the ore deposit.

A great number of researches were carried on the Xinmin polymetallic deposit, whereas its genesis remains controversial. On the basis of geological characteristics, stable isotopic analysis, and the mineralization temperature, there are two main views that were proposed to interpret its genesis, for example, (1) medium-high temperature skarn deposit [10] and (2) epithermal deposit [11]. However, our new data from the estimation of trapping pressure from fluid inclusions indicated that the Xinmin deposit has many differences from the typical epithermal deposit.
It has been widely accepted that the epithermal deposit generally forms at low temperatures $\left(<300^{\circ} \mathrm{C}\right)$, medium-low salinity fluids, and relatively low mineralization press $(<10 \mathrm{MPa})$ [44-46]. However, the microthermometric data in our work suggest that the ore-forming fluid in the Xinmin deposit is characterized by medium-high temperature $\left(485^{\circ} \mathrm{C}\right.$ to $205^{\circ} \mathrm{C}$ in main stage and $300^{\circ} \mathrm{C}$ to $116^{\circ} \mathrm{C}$ in late stage), medium-high salinity (2.7-50.7 wt.\%o $\mathrm{NaCl}$ equiv. in the main stage and $0.18-8.81$ wt.\%o in the late stage), and low trapping pressures $(2-30 \mathrm{MPa}$ in the main stage and $0.4-9 \mathrm{MPa}$ in the late stage). The temperature and salinity are obviously different from the epithermal deposit.

Furthermore, the occurrence of ore bodies in the Xinmin deposits is strictly controlled by the NS-trending fault 


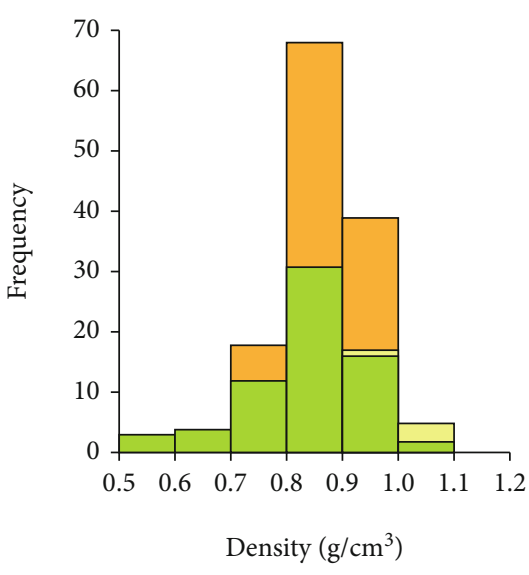

(a)

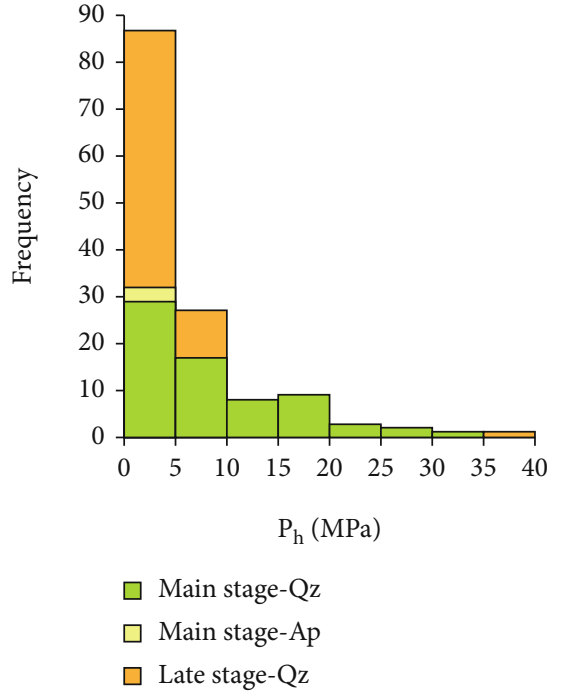

(b)

FIGURE 14: Histograms of densities (a) and pressure (b) of fluid inclusions in the main ore stage and the late stage. Ap: apatite; Qz: quartz.

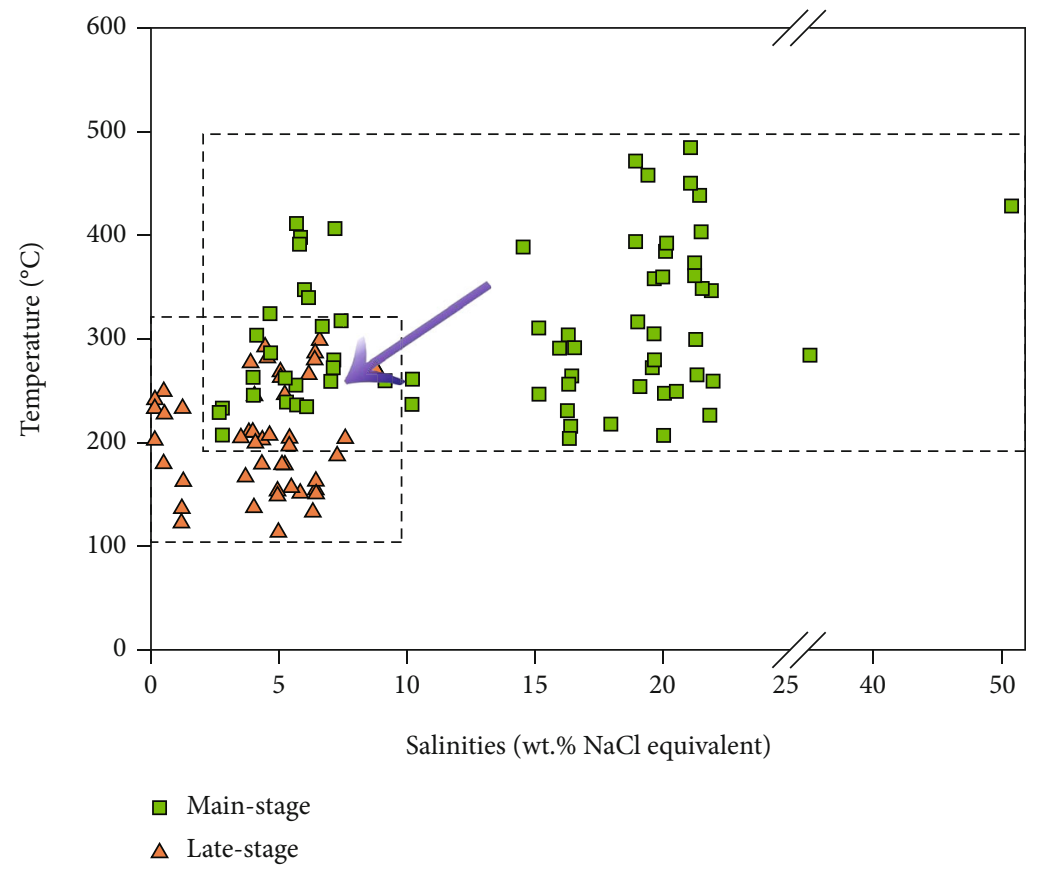

FIGURE 15: Homogenization temperature versus salinity plot of fluid inclusions showing fluid evolution in the Xinmin deposit.

and EW-trending shattered zone. The hydrothermal alterations associated with $\mathrm{Au}-\mathrm{Ag}-\mathrm{Cu}$ mineralization mainly include tourmalinization, chloritization, carbonation, and silicification. The gangue minerals include tourmaline, quartz, chlorite, apatite, and tremolite, which are not accordant with the typical characteristics of alternation in epithermal deposits [44-46], which can further rule out the possibility that the Xinmin deposit is a kind of epithermal deposit. Based on all available geological and geochemical evidence, we propose that the Xinmin polymetallic deposit belongs to a medium-high temperature hydrothermal deposit related to granitic magmatism controlled by fault and shattered zone instead of the epithermal deposit.

\section{Conclusions}

(1) The H-O-C-S-Pb isotope compositions indicated that the ore-forming fluids and ore metals were likely mainly derived from a magmatic-hydrothermal fluid for the Xinmin polymetallic deposit 
(2) Fluid inclusion studies indicate the homogenization temperatures and salinities in the main ore stage are $485^{\circ} \mathrm{C}$ to $205^{\circ} \mathrm{C}$ and $2.7-50.7$ wt. $\% \mathrm{NaCl}$ equiv., while in the late stage decrease to $300^{\circ} \mathrm{C}$ to $116^{\circ} \mathrm{C}$ and 0.18 8.81 wt. $\% \mathrm{NaCl}$ equiv., respectively

(3) The ore bodies of the Xinmin deposit strictly controlled by the NS-fault and EW-trending shattered zone, and the ore formation was due to the reduction of pressure and temperature of fluids in the hydrothermal mineralization system

(4) The Xinmin $\mathrm{Cu}-\mathrm{Au}-\mathrm{Ag}$ polymetallic deposit belongs to medium-high temperature, medium-high salinity hydrothermal deposit related to granitic magmatism

\section{Data Availability}

All the data in this study have been included in the paper as Tables 1-4.

\section{Conflicts of Interest}

The authors declare that they have no conflicts of interest.

\section{Acknowledgments}

This study was funded by grants from the National Natural Science Foundation of China (no. 41973044); the State Key Laboratory of Geological Processes and Mineral Resources, China University of Geosciences (no. MSFGPMR03-2); and the Guangdong Dabaoshan Mining Corporation Limited. We wish to thank Prof. Shui-Yuan Yang for helping with EPMA analyses, Prof. Kui-Dong Zhao for helping with LAMC-ICP-MS analyses, and Prof. Zi-Ren Wei for providing support in the fieldwork. Three anonymous reviewers provided helpful comments and suggestions that improved the quality of this manuscript.

\section{References}

[1] T. C. McCuaig, S. Beresford, and J. Hronsky, "Translating the mineral systems approach into an effective exploration targeting system," Ore Geology Reviews, vol. 38, no. 3, pp. 128-138, 2010.

[2] J. M. A. Hronsky, D. I. Groves, R. R. Loucks, and G. C. Begg, "A unified model for gold mineralisation in accretionary orogens and implications for regional-scale exploration targeting methods," Mineralium Deposita, vol. 47, no. 4, pp. 339-358, 2012.

[3] X. Cazañas, P. Alfonso, J. C. Melgarejo, J. A. Proenza, and A. E. Fallick, "Source of ore-forming fluids in El Cobre VHMSdeposit (Cuba): evidence from fluid inclusions and sulfur isotopes," Journal of Geochemical Exploration, vol. 78-79, pp. 85-90, 2003.

[4] A. Schmidt Mumm and M. Wolfgramm, "Stable isotope relationships of mineralisation in theNorth Eastern German Basin," Journal of Geochemical Exploration, vol. 78-79, pp. 261-265, 2003.

[5] J. Liu, J. W. Mao, G. Wu et al., "Fluid inclusions and H-O-S-Pb isotope systematics of the Chalukou giant porphyry Mo deposit, Heilongjiang Province, China," Ore Geology Reviews, vol. 59, pp. 83-96, 2014.

[6] X. H. Wang, Z. Q. Hou, Y. C. Song, and H. R. Zhang, "Geological, fluid inclusion and isotopic studies of the Baiyangping $\mathrm{Pb}-\mathrm{Zn}-\mathrm{Cu}-\mathrm{Ag}$ polymetallic deposit, Lanping basin, Yunnan province, China," Journal of Asian Earth Sciences, vol. 111, pp. 853-871, 2015.

[7] B. Mehrabi, E. T. Fazel, and B. Yardley, "Ore geology, fluid inclusions and O-S stable isotope characteristics of Shurab Sb-polymetallic vein deposit, eastern Iran," Geochemistry, vol. 79, no. 2, pp. 307-322, 2019.

[8] L. Alford, A. P. Gysi, N. C. Hurtig, T. Monecke, and K. Pfaff, "Porphyry-related polymetallic Au-Ag vein deposit in the Central City district, Colorado: mineral paragenesis and pyrite trace element chemistry," Ore Geology Reviews, vol. 119, article 103295, 2020.

[9] G. S. Liao, "The characteristic of technological mineralogy of gold-silver in Xinmin copper-polymetallic deposit, Guangxi," Journal of Mineralogy and Petrology, vol. 6, no. 1, pp. 61-67, 1985.

[10] L. J. Wang, C. Q. Hu, G. L. Zhang, and Z. H. Feng, “The occurrence of gold and silver of Xinmin copper and silver polymetallic deposit, Guangxi," Journal of Guilin Institute of Technology, vol. 15, no. 2, pp. 131-136, 1995.

[11] Z. R. Wei and Y. H. Zhang, The Prospecting Direction of Longshan Gold Field in Guigang, Guangxi Province, Southern Territorial Resources, 2003.

[12] J. W. Mao, M. H. Chen, S. D. Yuan, and C. L. Guo, "Geological characteristics of the Qinhang (or Shihang) metallogenic belt in South China and spatial-temporal distribution regularity of mineral deposits," Acta Geologica Sinica, vol. 85, no. 5, pp. 636-658, 2011.

[13] L. S. Shu, M. Faure, J. H. Yu, and B. M. Jahn, “Geochronological and geochemical features of the Cathaysia block (South China): new evidence for the Neoproterozoic breakup of Rodinia," Precambrian Research, vol. 187, no. 3-4, pp. 263-276, 2011.

[14] Y. Z. Zhou, C. Y. Zeng, H. Z. Li et al., "Geological evolution and ore-prospecting targets in southern segment of Qinzhou Bay-Hangzhou Bay juncture orogenic belt, southern China," Geological Bulletin of China, vol. 31, no. 2-3, pp. 486-491, 2012.

[15] Y. Wang, W. Fan, G. Zhang, and Y. Zhang, "Phanerozoic tectonics of the South China Block: key observations and controversies," Gondwana Research, vol. 23, no. 4, pp. 1273-1305, 2013.

[16] M. H. Chen, Z. Y. Li, Q. Li et al., "A preliminary study of multistage granitoids and related metallogenic series in Dayaoshan area of Guangxi, China," Earth Science Frontiers, vol. 22, no. 2, pp. 041-053, 2015.

[17] R. C. Duan, W. L. Ling, Q. Li, Z. W. Chen, H. M. Yang, and L. F. Liu, "Correlations of the Late Yanshanian tectonomagmatic events with metallogenesis in South China: geochemical constraints from the Longtoushan gold ore deposit of the Dayaoshan Area, Guangxi province," Acta Geologica Sinica, vol. 85, no. 10, pp. 1644-1658, 2011.

[18] F. W. Chen, H. Q. Li, and Y. P. Mei, “Zircon SHRIMP U-Pb chronology of diagenetic mineralization of the Longtoushan porphyry gold orefield, Gui County, Guangxi," Acta Geologica Sinica, vol. 82, pp. 921-926, 2008.

[19] D. L. Whitney and B. W. Evans, "Abbreviations for names of rock-forming minerals," American Mineralogist, vol. 95, no. 1 , pp. 185-187, 2010. 
[20] T. Liu, S. F. Xiong, S. Y. Jiang, H. L. Li, Q. Z. Chen, and $\mathrm{H}$. Jiang, "Genesis of the Zhijiadi Ag-Pb-Zn deposit, central North China Craton: constraints from fluid inclusions and stable isotope data," Geofluids, vol. 2017, Article ID 4153618, 23 pages, 2017.

[21] S. F. Thornton, K. M. Baker, S. H. Bottrell et al., "Enhancement of in situ biodegradation of organic compounds in groundwater by targeted pump and treat intervention," Applied Geochemistry, vol. 48, pp. 28-40, 2014.

[22] Z. Y. Zhu, S. Y. Jiang, C. L. Ciobanu, T. Yang, and N. J. Cook, "Sulfur isotope fractionation in pyrite during laser ablation: Implications for laser ablation multiple collector inductively coupled plasma mass spectrometry mapping," Chemical Geology, vol. 450, pp. 223-234, 2017.

[23] Z. Y. Zhu, N. L. Cook, T. Yang, C. L. Ciobanu, K. D. Zhao, and S. Y. Jiang, "Mapping of sulfur isotopes and trace elements in sulfides by LA-(MC)-ICP-MS: potential analytical problems, improvements and implications," Minerals, vol. 6, no. 4, p. 110, 2016.

[24] J. L. Haas, "Physical properties of the coexisting phases and thermochemical properties of the $\mathrm{H}_{2} \mathrm{O}$ component in boiling $\mathrm{NaCl}$ solution," US Geological Survey Bulletin, vol. 1421-A, pp. 1-73, 1976.

[25] R. N. Clayton, I. Friedman, D. L. Graf, T. K. Mayeda, W. F. Meents, and N. F. Shimp, "The origin of saline formation waters: 1. Isotopic composition," Journal of Geophysical Research, vol. 71, no. 16, pp. 3869-3882, 1966.

[26] K. D. Zhao, S. Y. Jiang, P. Ni, H. F. Ling, and Y. H. Jiang, "Sulfur, lead and helium isotopic compositions of sulfide minerals from the Dachang Sn-polymetallic ore district in South China: implication for ore genesis," Mineralogy and Petrology, vol. 89, no. 3-4, pp. 251-273, 2007.

[27] D. L. Hall, S. M. Sterner, and R. J. Bodnar, "Freezing point depression of NaCl-KCl-H 2 O solutions," Economic Geology, vol. 83, no. 1, pp. 197-202, 1988.

[28] B. Liu and G. X. Duan, "The density and isochoric formulae for $\mathrm{NaCl}-\mathrm{H}_{2} \mathrm{O}$ fluid inclusions (salinity $\leq 25 \mathrm{wt} \%$ ) and their applications," Acta Mineralogica Sinica, vol. 7, no. 4, pp. 345-352, 1987.

[29] B. Liu, "Density and isochoric formulae for $\mathrm{NaCl}-\mathrm{H}_{2} \mathrm{O}$ inclusions with medium and high salinity and their applications," Geological Review, vol. 47, no. 6, pp. 617-622, 2001.

[30] T. B. Coplen, C. Kendall, and J. Hopple, "Comparison of stable isotope reference samples," Nature, vol. 302, no. 5905, pp. 236-238, 1983.

[31] H. Ohmoto and R. Rye, "Isotopes of sulfur and carbon," in Geochemistry of Hydrothermal Ore Deposits, H. L. Barnes, Ed., pp. 509-567, Wiley \& Sons Inc., New York, NY, USA, 1979.

[32] H. Ohmoto, "Stable isotope geochemistry of ore deposits," Reviews in Mineralogy, vol. 16, pp. 491-559, 1986.

[33] H. P. Taylor, "The application of oxygen and hydrogen isotope studies to problems of hydrothermal alteration and ore deposition," Economic Geology, vol. 69, no. 6, pp. 843-883, 1974.

[34] J. W. Hedenquist and J. B. Lowenstern, "The role of magmas in the formation of hydrothermal ore deposit," Nature, vol. 370, pp. 495-510, 1994.

[35] J. Chen and H. N. Wang, Geochemistry, Science Press, Beijing, 2004.

[36] Y. F. Zheng and J. F. Chen, Stable Isotopic Geochemistry, Science Press, Beijing, 2000.
[37] J. Liu, M. Zheng, N. J. Cook, X. Long, J. Deng, and Y. Zhai, "Geological and geochemical characteristics of the Sawaya'erdun gold deposit, southwestern Chinese Tianshan," Ore Geology Reviews, vol. 32, no. 1-2, pp. 125-156, 2007.

[38] H. Ohmoto, "Systematics of sulfur and carbon isotopes in hydrothermal ore deposits," Economic Geology, vol. 67, no. 5, pp. 551-578, 1972.

[39] J. Hoefs, Stable Isotope Geochemistry, Springer-Verlag, Berlin, Heidelberg, 6th edition, 2009.

[40] E. A. Firth, D. A. Holwell, N. H. S. Oliver, J. K. Mortensen, M. P. Rovardi, and A. J. Boyce, "Constraints on the development of orogenic style gold mineralisation at Mineral de Talca, Coastal Range, central Chile: evidence from a combined structural, mineralogical, $\mathrm{S}$ and $\mathrm{Pb}$ isotope and geochronological study," Mineralium Deposita, vol. 50, pp. 657-696, 2015.

[41] J. B. Lowenstern, "Carbon dioxide in magmas and implications for hydrothermal systems," Mineralium Deposita, vol. 36, no. 6, pp. 490-502, 2001.

[42] H. L. Barnes, "Solubilities of ore minerals," in Geochemistry of Hydrothermal Ore Deposits, H. L. Barnes, Ed., pp. 404-460, Wiley, New York, NY, USA, 1979.

[43] D. A. Crerar and H. L. Barnes, "Ore solution chemistry; V, solubilities of chalcopyrite and chalcocite assemblages in hydrothermal solution at 200 degrees to 350 degrees C," Economic Geology, vol. 71, no. 4, pp. 772-794, 1976.

[44] G. H. Brimhall and D. A. Crerar, "Ore fluids: magmatic to supergene," Reviews in Mineralogy and Geochenistry, vol. 17, pp. 235-321, 1987.

[45] H. F. Bonham, "Models for volcanic-hosted epithermal precious metal deposit: a review," in Proceedings of the International Volcanological Congress, Symposium 5, pp. 13-17, Hamiltion, New Zealand, 1986.

[46] P. Heald, N. K. Foley, and D. O. Hayba, "Comparative anatomy of volcanic-hosted epithermal deposits; acid-sulfate and adularia-sericite types," Economic Geology, vol. 82, no. 1, pp. 1-26, 1987. 